\title{
Enzyme-injected method of enzymatic dispersion at low temperature is effective for isolation of smooth muscle cells from human esophagogastric junction
}

\author{
YANG GAO $^{1,2}$, JUN-FENG LIU ${ }^{1}$, CHAO ZHANG ${ }^{3}$, LIANG LIU ${ }^{4}$, \\ YUE-PING LIU ${ }^{5}$, SHENG-LEI ZHANG ${ }^{6}$ and LIAN-MEI ZHAO ${ }^{3}$
}

\author{
${ }^{1}$ Department of Thoracic Surgery, The Fourth Hospital of Hebei Medical University, Shijiazhuang, Hebei 050011; \\ ${ }^{2}$ Graduate School of Hebei Medical University, Shijiazhuang, Hebei 050017; ${ }^{3}$ Research Center; ${ }^{4}$ Tumor Institute; \\ Departments of ${ }^{5}$ Pathology and ${ }^{6}$ Nephrology, The Fourth Hospital of Hebei Medical University, \\ Shijiazhuang, Hebei 050011, P.R. China
}

Received January 15, 2019; Accepted January 9, 2020

DOI: $10.3892 / \mathrm{etm} .2020 .8560$

\begin{abstract}
The present study was conducted to examine the feasibility of in vitro isolation and primary culture of smooth muscle cells (SMCs) from the esophagogastric junction (EGJ). Smooth muscles of EGJ were harvested from 23 patients with esophageal cancer during esophagostomy from January 2015 to December 2017. Enzymatic dispersion (ED) was performed for isolation. Collagenase II and Trypsin/EDTA were applied by enzyme injection (EI) into tissue fragments or immersion of tissue fragments into enzyme solution. Growth characteristics and proliferation [Cell Counting Kit-8 (CCK-8)] of cells were recorded for both smooth muscle cell medium (SMCM) and DMEM/F12 containing 10\% newborn bovine serum (10\%-F12). All ED methods could isolate primary cells; EI was the most effective method with low collagenase II concentration $(0.5 \mathrm{mg} / \mathrm{ml})$ at $4^{\circ} \mathrm{C}$ for $14-24 \mathrm{~h}$. Primary cells demonstrated mainly spindle- and long-spindle-shaped with 'hills and valleys' morphology. The CCK-8 assay in SMCM showed better proliferation results than in $10 \%-\mathrm{F} 12$. After passaging for 4-8 generations in SMCM or 2-4 generations in $10 \%-\mathrm{F} 12$, cells enlarged gradually with passages and lost spindle structures. mRNA and proteins of $\alpha$-smooth muscle actin ( $\alpha$-SMA), smooth muscle $22 \alpha(\operatorname{SM} 22 \alpha)$, vimentin, desmin, CD90 and proliferating cell nuclear antigen were detected in tissues and cells with different levels of expression. SMCs of esophageal circular muscle, esophageal longitudinal muscle, gastric circular muscle near sling in gastric bottom and gastric circular muscle near clasp in lesser gastric curvature,
\end{abstract}

Correspondence to: Professor Jun-Feng Liu, Department of Thoracic Surgery, The Fourth Hospital of Hebei Medical University, 12 Jiankang Road, Chang'an, Shijiazhuang, Hebei 050011, P.R. China E-mail: liujf@hbmu.edu

Key words: esophagogastric junction, smooth muscle myocytes, primary cell culture, smooth muscle, identification all cultured in 10\%-F12, exhibited superior smooth muscle phenotypes compared with SMCs cultured in SMCM in terms of $\alpha$-SMA, SM22 $\alpha$ and vimentin expression. The EI method of ED at low temperature appears effective for isolation and primary culture of SMCs from human EGJ in vitro.

\section{Introduction}

Primary culture of smooth muscle cells (SMCs) is an established method in the study of vascular physiology and pathophysiology (1-3). Many researchers have performed primary culture of human gastrointestinal/esophageal SMCs (4-6); enzymatic dispersion (ED) is the most common method. At least two enzymes with one or two processes/steps were typically used in previous studies (7-10); however, to the best of the authors' knowledge, there are no corresponding established or systematic processes of SMC culture in the digestive system, including detailed identification using smooth muscle markers. Gargus et al (7), Rieder et al (11) and Niu et al (12) introduced processes for primary culture and identification of human esophageal SMCs and fibroblasts in vitro; however, these processes are relatively complicated and lack detailed identification methods.

Collagenase II is one of the most commonly used enzymes in the isolation of primary SMCs $(3,8,11,13)$. Immersing tissue fragments directly in collagenase solution for $0.5-6 \mathrm{~h}$ at $37^{\circ} \mathrm{C}$ is the most common isolation method $(7,9,11,12)$. In contrast to the traditional method, in the present study, smooth muscles were collected from the tumor-free esophagogastric junction (EGJ) of patients with esophageal carcinoma and the traditional method was improved by using an enzyme-injected (EI) method for SMC isolation at low temperature $\left(4^{\circ} \mathrm{C}\right)$ for an extended duration (14-24 h). Through comparative observation, it was identified that it was effective in isolating more adherent spindle cells and that the cells could proliferate in vitro for 3-8 generations of SMC primary culture, as indicated by identification with smooth muscle markers, including $\alpha$-smooth muscle actin ( $\alpha$-SMA) (13-15), smooth muscle $22 \alpha(\operatorname{SM} 22 \alpha)(14-16)$, vimentin $(7,8)$, desmin $(7,17)$ 
and CD90 (7,18). The present study identified improved processes for in vitro culture of SMCs obtained from the digestive tract and established a foundation for the study of primary esophageal motility disorders (PEMDs), gastroesophageal reflux diseases (GERDs) and tissue engineering of the esophagus.

\section{Materials and methods}

Patients and specimens. The present study was approved by The Medical Ethics Committee of The Fourth Hospital of Hebei Medical University. Informed consent was obtained from the patients or their authorized relatives. Smooth muscles of EGJ were obtained from patients diagnosed at the Thoracic Department, Fourth Hospital of Hebei Medical University undergoing esophagectomy for upper esophageal carcinoma. Patients had no symptoms of heartburn and regurgitation, nor had any medical history of esophageal dysfunction or treatment with calcium channel blockers. A total of 23 patients agreed to provide tissue specimens for the present study during the period from January 2015 to December 2017, including 15 men and 8 women with a mean age of $60.26 \pm 6.32$ years; range, 49-71 years.

EGJ tissues were removed during surgery (19). Through examination of muscle fibers, esophageal circular (EC) muscle, esophageal longitudinal (EL) muscle, sling fiber (Sling), clasp fiber (Clasp), gastric circular muscle near sling in gastric bottom (GC-S) and gastric circular muscle near clasp in lesser gastric curvature (GC-C) were identified. Smooth muscles were prepared in 5-15x5-10 mm strips. Samples from the same patient were divided into three parts: i) One part was used for isolation of SMCs and was quickly placed into a $1.5 \mathrm{ml}$ Eppendorf tube with $1 \mathrm{ml} \mathrm{DMEM} / \mathrm{F} 12$ (Thermo Fisher Scientific, Inc.) and $200 \mu \mathrm{l}$ penicillin/streptomycin $(\mathrm{P} / \mathrm{S})$ solution (Biological Industries); ii) another was used for immunohistochemistry (IHC) and was immediately immersed in $10 \%$ neutral formalin at room temperature for 8-12 h; and iii) one was used for reverse transcription-quantitative PCR (RT-qPCR) and was immersed in RNAlater (Thermo Fisher Scientific, Inc.) and stored at $-80^{\circ} \mathrm{C}$.

Hematoxylin and eosin $(H \& E)$ staining. Smooth muscles immersed in $10 \%$ neutral formalin were embedded in paraffin, and were cut into $4-\mu \mathrm{m}$ sections for $\mathrm{H} \& \mathrm{E}$ staining Following deparaffinization in xylene and hydration in descending concentrations of alcohol, sections were stained in hematoxylin for 3 min followed washing in running tap water. Sections were differentiatedin $1 \% \mathrm{HCl}$ in $70 \%$ alcohol for $30 \mathrm{sec}$. Sections were then dipped in $0.6 \%$ ammonia water followed by washing in tap water until the nuclei were stained blue. Following staining in $1 \%$ eosin for 3 min and a tap water wash, sections were dehydrated in increasing concentrations of alcohols and cleared in xylene. Two pathologists measured the morphology of SMCs in these sections. SMCs were observed in bundles without heteromorphism under a light microscope (TE2000-U; Nikon Corporation) at x200 magnification. Eosinophilic cytoplasms were stained pink. The nuclei were oval, without heteromorphism or mitosis. No tumor cells were contained in smooth muscle tissues.
Primary culture of SMCs: EI method of ED. Smooth muscle strips were cut into 5-8x5 mm fragments and soaked in collagenase II (Vetec ${ }^{\mathrm{TM}}$; Sigma-Aldrich; Merck KGaA) DMEM/F12 solutions with concentrations of either $0.5 \mathrm{mg} / \mathrm{ml}$ or $1 \mathrm{mg} / \mathrm{ml}$ were mixed with $\geq 125 \mathrm{CDU} / \mathrm{mg}$ collagenase II. The solution volume was 5-6-fold greater than the tissue volume. DMEM/F12 mixed with collagenase II (0.1-0.2 ml) was injected into the fragments, which were then digested at $4^{\circ} \mathrm{C}$ for $14-24 \mathrm{~h}$. A total of 400-600 $\mu \mathrm{l}$ newborn bovine serum (NBS; Biological Industries) was mixed into the solution to terminate digestion with soft suction piping for $5 \mathrm{~min}$ to isolate cells. Following filtration by sieving through a nylon net (200- $\mu \mathrm{m}$ aperture), the filtrate was centrifuged at $100 \mathrm{x} \mathrm{g}$ for $5 \mathrm{~min}$ at room temperature. The resulting precipitate was suspended with $1 \mathrm{ml}$ smooth muscle cell medium (SMCM; ScienCell Research Laboratories, Inc.) and placed in six-well plates pre-layered with $0.1 \mathrm{mg} / \mathrm{ml}$ poly-L-lysine (Sigma-Aldrich; Merck KGaA). Cells were placed in a humidified incubator with $5 \% \mathrm{CO}_{2}$ at a temperature of $37^{\circ} \mathrm{C}$. After $48 \mathrm{~h}$, the wells were gently flushed with PBS and $2 \mathrm{ml} \mathrm{SMCM}$ was added. This constituted the EI method. Primary cells were dispersed with $0.25 \%$ Trypsin/EDTA and sub-cultured in two flasks when cells were closely arranged and crowded. The number of days during primary cell adherence to sub-culture with $0.25 \%$ Trypsin/EDTA was defined as the first passage day (FPD).

These two groups described, in which $0.5 \mathrm{mg} / \mathrm{ml}$ or $1 \mathrm{mg} / \mathrm{ml}$ collagenase II solution was injected into the tissues at $4^{\circ} \mathrm{C}$, were defined as the 0.5 -EI-4 group and the 1-EI- 4 group, respectively. Other conditions were modified to compare with the two groups. First, smooth muscles were cut into $1-3 \times 1-3 \mathrm{~mm}$ fragments, then digested at $37^{\circ} \mathrm{C}$ with $1 \mathrm{mg} / \mathrm{ml}$ collagenase II solution for $1 \mathrm{~h}$ (1-C-37 group), or digested at $4^{\circ} \mathrm{C}$ with $0.5 \mathrm{mg} / \mathrm{ml}$ collagenase II solution for $14-24 \mathrm{~h}$ (0.5-C-4 group). These comprised two traditional methods to isolate SMCs in vitro. Second, smooth muscles were cut into $1-3 \times 1-3 \mathrm{~mm}$ fragments, then digested at $37^{\circ} \mathrm{C}$ with $0.25 \%$ Trypsin/EDTA for $1 \mathrm{~h}$ (0.25-T-37 group), or digested at $4^{\circ} \mathrm{C}$ with $0.125 \%$ Trypsin/EDTA for $14-24 \mathrm{~h}$ (0.125-T-4 group), to test whether Trypsin/EDTA was effective for ED of SMCs.

After $72 \mathrm{~h}$, the number of visible adherent cells per field were visualized under a light microscope (TE2000-U; Nikon Corporation) at x200 magnification. The FPD was used to evaluate the effectiveness of each method. The most effective method was selected for subsequent experiments.

Cell culture and proliferation test. Cells were passaged and continuously cultured in SMCM (the second generation of SMCM cultured cells), or replaced with DMEM/F-12 containing $10 \%$ NBS $(10 \%-F 12$; the first generation of $10 \%$-F12 cultured cells). Cells were defined as ED (SMCM) and ED (10\%-F12) as cultured by SMCS and 10\%-F12, respectively.

The third generation of cells cultured in SMCM and the second generation of cells cultured in 10\%-F12 were tested for proliferation. Cells were cultured in 3 wells of 96-well plates with $2 \times 10^{3}$ cells/well. According to the manufacturer's protocol of the Cell Counting Kit-8 (CCK-8; Dojindo Molecular Technologies, Inc.), the absorbance of each well per $24 \mathrm{~h}$ was continuously measured over 9 days (216 h). 
Table I. Catalog numbers and dilutions of antibodies used in the present study.

A, Primary antibody

\begin{tabular}{|c|c|c|c|c|}
\hline Name & Supplier & Cat. no. & Dilution & Application \\
\hline Mouse anti- $\alpha-S M A$ & Abcam & ab7817 & $1: 100$ & $\mathrm{IHC}, \mathrm{IF}$ \\
\hline Rabbit anti- $\alpha-S M A$ & Abcam & ab124964 & $1: 100$ & IF, ICW \\
\hline Rabbit anti-vimentin & Abcam & ab92547 & $1: 100$ & $\mathrm{IHC}, \mathrm{IF}, \mathrm{ICW}$ \\
\hline Goat anti-desmin & Santa Cruz Biotechnology, Inc. & sc-7559 & $1: 100$ & IF \\
\hline Mouse anti-desmin & Santa Cruz Biotechnology, Inc. & sc-23879 & $1: 50$ & $\mathrm{IHC}, \mathrm{IF}, \mathrm{ICW}$ \\
\hline Mouse anti-CD90 & Abcam & ab181469 & $1: 200$ & $\mathrm{IHC}, \mathrm{IF}, \mathrm{ICW}$ \\
\hline Rabbit anti-SM22 $\alpha$ & Abcam & ab14106 & $1: 100$ & IHC, IF, ICW \\
\hline Mouse anti-PCNA & Abcam & ab29 & $1: 200$ & $\mathrm{IHC}, \mathrm{IF}, \mathrm{ICW}$ \\
\hline Mouse anti-GAPDH & Abcam & $\mathrm{ab} 8245$ & $1: 500$ & IF, ICW \\
\hline Rabbit anti-GAPDH & Abcam & ab181602 & $1: 500$ & IF, ICW \\
\hline
\end{tabular}

B, Secondary antibody

\begin{tabular}{|c|c|c|c|c|}
\hline Name & Supplier & Cat. no. & Dilution & Application \\
\hline Goat anti-rabbit/mouse IgG & Servicebio, Beijing, China & GB1210 & Ready to use & IHC \\
\hline Donkey anti-mouse IgG 647 & Abcam & ab150107 & $1: 200$ & IF \\
\hline Donkey anti-rabbit IgG 488 & Thermo Fisher Scientific, Inc. & $-A-21206$ & $1: 200$ & $\mathrm{IF}$ \\
\hline Donkey anti-goat IgG 555 & Abcam & ab150130 & $1: 200$ & IF \\
\hline Goat anti-rabbit IgG 549 & KPL, Inc. & $072-04-15-06$ & $1: 200$ & IF \\
\hline Goat anti-mouse IgG 488 & KPL, Inc. & $072-03-18-06$ & $1: 200$ & IF \\
\hline $\begin{array}{l}\text { Goat anti-mouse IgG IRDye } \\
800 \mathrm{CW}\end{array}$ & $\begin{array}{l}\text { Rockland Immunochemicals, } \\
\text { Inc. }\end{array}$ & 25340 & $1: 5,000$ & $\mathrm{ICW}$ \\
\hline $\begin{array}{l}\text { Donkey anti-rabbit IgG } \\
\text { (Alexa Fluor }{ }^{\circledR} 680 \text { ) }\end{array}$ & Abcam & ab175772 & $1: 5,000$ & ICW \\
\hline
\end{tabular}

$\alpha$-SMA, $\alpha$-smooth muscle actin; PCNA, proliferating cell nuclear antigen; IHC, immunohistochemistry; IF, immunofluorescence; ICW, in-cell western.

Identification of SMCs. SMCs were identified by the expression of the following markers: $\alpha$-SMA, SM $22 \alpha$, vimentin, desmin and CD90. Proliferation potential was evaluated by proliferating cell nuclear antigen (PCNA) (20-22). The third generation of cells cultured in SMCM and the second generation of cells cultured in 10\%-F12 were tested.

IHC. IHC and scoring were conducted as described for smooth muscles (23). Two pathologists, blinded to tissue details, measured the extent of marker expression. Expression was scored as follows: 9-12, strong; 5-8, moderate; $1-4$, weak; and 0 , negative. Detailed antibody information is presented in Table I.

$R T$ - $q P C R$. Total RNA was extracted using TRIzol ${ }^{\circledR}$ (TriQuick Reagent total RNA extraction kit; Invitrogen; Thermo Fisher Scientific, Inc.) and phenol-chloroform extraction, using either frozen muscle samples or cultured cells (that were grown to the third generation in SMCM and the second generation in $10 \%$-F12). The integrity of the RNA was verified by $2 \%$ agarose gel electrophoresis and ethidium bromide staining at $160 \mathrm{~V}$ for $15 \mathrm{~min}$. In total, $3 \mu \mathrm{g}$ total RNA was reverse transcribed with random hexamers using a Thermo RT kit (Thermo Fisher Scientific, Inc.) and a Veriti PCR system (Thermo Fisher Scientific, Inc.). The following heat cycle was used for RT: Annealing at $25^{\circ} \mathrm{C}$ for 5 min extension at $42^{\circ} \mathrm{C}$ for $1 \mathrm{~h}$ and reverse transcriptase inactivation at $70^{\circ} \mathrm{C}$ for $5 \mathrm{~min}$. Samples were subsequently stored at $4^{\circ} \mathrm{C}$.

Each real-time PCR reaction comprised $2 \mu \mathrm{l}$ RT product, $5 \mu \mathrm{l}$ SYBR Green qPCR Super Mix (Thermo Fisher Scientific, Inc.), $0.8 \mu 1$ mixture of forward and reverse primers at 100-fold dilution, and $2.2 \mu 1$ nuclease-free water. Reactions were performed in an ABI 7500 Real-Time PCR System (Thermo Fisher Scientific, Inc.) for 40 cycles $\left(95^{\circ} \mathrm{C}\right.$ for $30 \mathrm{sec}$, optimum temperature for $30-40 \mathrm{sec}$ and $72^{\circ} \mathrm{C}$ for $30-40 \mathrm{sec}$ ). In the present study, each group was treated as an independent sample (not paired samples), and the expression level of smooth muscle markers in EGJ smooth muscles and cells cultured in vitro was not clear. The purpose of the present study was to clarify the characteristics of the expression levels of smooth muscle markers in EGJ smooth muscles and cells cultured in vitro, rather than to standardize or homogenize them to compare the expression level of one gene to the others, so there was no blank control group and the fold change in expression 
Table II. Primer information.

\begin{tabular}{|c|c|c|c|c|}
\hline Gene & Direction & Sequence, $5^{\prime}-3^{\prime}$ & $\mathrm{AT},{ }^{\circ} \mathrm{C}$ & Products, bp \\
\hline \multirow[t]{2}{*}{$\alpha-\mathrm{SMA}$} & $\mathrm{F}$ & GCGACCCTAAAGCTTCCCAG & 60 & 145 \\
\hline & $\mathrm{R}$ & TTCTTGGGCCTTGATGCGAA & & \\
\hline \multirow[t]{2}{*}{ Vimentin } & $\mathrm{F}$ & GAGAACTTTGCCGTTGAAGC & 59 & 170 \\
\hline & $\mathrm{R}$ & TCCAGCAGCTTCCTGTAGGT & & \\
\hline \multirow[t]{2}{*}{ Desmin } & $\mathrm{F}$ & GATCCAGTCCTACACCTGCG & 58 & 96 \\
\hline & $\mathrm{R}$ & TCACTGGCAAATCGGTCCTC & & \\
\hline \multirow[t]{2}{*}{ CD90 } & $\mathrm{F}$ & AAGAGCAGACCTTCTCTGGGTC & 59 & 313 \\
\hline & $\mathrm{R}$ & GCGGCTGCAGCTACAATCAA & & \\
\hline \multirow[t]{2}{*}{ SM22 $\alpha$} & $\mathrm{F}$ & AACAGCCTGTACCCTGATGG & 61 & 239 \\
\hline & $\mathrm{R}$ & CGGTAGTGCCCATCATTCTT & & \\
\hline \multirow[t]{2}{*}{ PCNA } & $\mathrm{F}$ & GTAGTAAAGATGCCTTCTGGTG & 60 & 190 \\
\hline & $\mathrm{R}$ & TCTCTATGGTAACAGCTTCCTC & & \\
\hline \multirow[t]{2}{*}{ GAPDH } & $\mathrm{F}$ & CGCTGAGTACGTCGTGGAGTC & - & 172 \\
\hline & $\mathrm{R}$ & GCTGATGATCTTGAGGCTGTTGTC & & \\
\hline
\end{tabular}

$\alpha$-SMA, $\alpha$-smooth muscle actin; SM22 $\alpha$, smooth muscle $22 \alpha$; PCNA, proliferating cell nuclear antigen; F, forward; R, reverse; AT, annealing temperature.

of each gene was calculated using the $2^{-\Delta \Delta \mathrm{Cq}}$ method (24-26), with GAPDH as an internal control. Primer information is presented in Table II.

Immunofluorescence. Cells were fixed with $4 \%$ paraformaldehyde for 30-60 min at room temperature. After permeation with $0.3 \%$ (v/v) Triton X-100 (Sigma-Aldrich; Merck KGaA) for $5 \mathrm{~min}$ and blocking with $5 \%$ BSA-PBS for $1 \mathrm{~h}$ at room temperature, cells were incubated with primary antibodies for $12 \mathrm{~h}$ at $4^{\circ} \mathrm{C}$; they were then washed three times with PBS. Cells were incubated with Secondary antibodies for $1 \mathrm{~h}$ at room temperature to visualize the binding of anti- $\alpha$-SMA, anti-SM22 $\alpha$, anti-vimentin, anti-desmin, anti-CD90 and anti-PCNA antibodies. Nuclear staining was performed with 4',6'-DAPI (Sigma-Aldrich; Merck KGaA) for $5 \mathrm{~min}$ at room temperature. The images were viewed using a confocal laser scanning microscope (LSM 510; Zeiss AG) at x200 magnification. Detailed antibody information is presented in Table I.

In-cell western. Cells (6-8x103/200 $\mu \mathrm{l} /$ well) were transferred to black 96-well plates (cat. no. 3603; Corning, Inc.) at room temperature during the process of subculture. After adherence for $6 \mathrm{~h}$, the medium was removed. Experimental procedures were performed as described in a previous study by Henrich (27). Using the concentrations shown in Table I, primary antibodies (mouse/rabbit) and anti-GAPDH (rabbit/mouse) were premixed together in 2\% BSA-PBS. The dilutions of goat anti-mouse IgG 800 (cat. no. 25340; Rockland Immunochemicals, Inc.) and anti-rabbit IgG 680 (cat. no. ab175772; Abcam) antibodies were 1:5,000, premixed in $2 \%$ BSA-PBS. After the final washes, plates were scanned on the Odyssey Imaging System (UL3101-1, LI-COR Biosciences) using the 'In-Cell Western' mode to capture relative fluorescence in each channel. The formula of relative protein expression was as follows: Relative expression of target protein $=$ Fluorescence intensity of target protein (700/800)/Fluorescence intensity of GAPDH (800/700).

Statistical analysis. Statistical analysis was conducted with SPSS 13.0 (SPSS, Inc.). For measurement data with normal distribution and variance, samples are presented as the mean \pm SD in tables or histograms and standard deviations in figures. A total of two independent samples t-tests were used in two group comparisons, and one-way ANOV followed by Student-Newman-Keuls post-hoc test was performed for multiple group comparisons. Measurement data that were neither normal nor homogeneous were recorded as median (interquartile range) in tables or box plots in figures (28-30), followed by Wilcoxon rank sum test (31). Box plots can be selected for normal and non-normal distribution data with distribution characteristics, including the median, the approximate quartiles, and the lowest and highest data points to convey the level, spread and symmetry (28). For IHC staining (count data), specimens were evaluated as strong, moderate, weak or negative expression, without further statistical comparison. $\mathrm{P}<0.05$ was considered to indicate a statistically significant difference.

\section{Results}

Patient information. General information on patient characteristics is shown in Table III.

ED with tissue fragments. In the present study, all types of ED methods could isolate adherent cells that grew in culture. There were no differences in morphology among cells obtained by these methods. Therefore, both collagenase II and Trypsin/EDTA can be selected as working enzymes for the ED method of SMC isolation. Cells were spindle- or long-spindle-shaped and some were rod-like. Few fibroblasts 
Table III. Patient information.

\begin{tabular}{|c|c|c|c|c|c|c|c|c|c|c|c|c|}
\hline \multirow{2}{*}{$\begin{array}{l}\text { Patients } \\
\text { number }\end{array}$} & \multirow[b]{2}{*}{ Sex } & \multirow{2}{*}{$\begin{array}{c}\text { Age } \\
\text { (years) }\end{array}$} & \multirow{2}{*}{$\begin{array}{l}\text { Smooth } \\
\text { muscle } \\
\text { species }\end{array}$} & \multirow[b]{2}{*}{$\mathrm{H} \& \mathrm{E}$} & \multirow{2}{*}{$\begin{array}{l}\text { Primary } \\
\text { culture }\end{array}$} & \multicolumn{2}{|c|}{ Cell generations } & \multirow{2}{*}{$\begin{array}{l}\text { Proliferation } \\
\text { test }\end{array}$} & \multirow[b]{2}{*}{ IHC } & \multirow[b]{2}{*}{ RT-qPCR } & \multirow[b]{2}{*}{ IF } & \multirow{2}{*}{$\begin{array}{l}\text { In-cell } \\
\text { western }\end{array}$} \\
\hline & & & & & & SMCM & $10 \%-\mathrm{F} 12$ & & & & & \\
\hline 1 & $\mathrm{M}$ & 57 & 6 & Yes & Yes & 6 & 2 & - & - & - & - & - \\
\hline 2 & $\mathrm{M}$ & 63 & 6 & Yes & Yes & 7 & 3 & - & - & - & - & - \\
\hline 3 & $\mathrm{~F}$ & 65 & 6 & Yes & Yes & 5 & 4 & - & - & - & - & - \\
\hline 4 & M & 67 & 6 & Yes & Yes & 6 & 3 & - & - & - & - & - \\
\hline 5 & $\mathrm{~F}$ & 69 & 6 & Yes & Yes & 5 & 3 & - & - & - & - & - \\
\hline 6 & M & 57 & 6 & Yes & Yes & 4 & 4 & - & - & - & - & - \\
\hline 7 & $\mathrm{~F}$ & 50 & 6 & Yes & Yes & 7 & 3 & - & - & - & - & - \\
\hline 8 & M & 71 & 6 & Yes & Yes & 5 & 3 & Yes & - & - & - & - \\
\hline 9 & M & 68 & 6 & Yes & Yes & 6 & 4 & Yes & - & - & - & - \\
\hline 10 & $\mathrm{M}$ & 62 & 6 & Yes & Yes & 5 & 3 & Yes & - & - & - & - \\
\hline 11 & $\mathrm{~F}$ & 56 & 6 & Yes & Yes & 6 & 4 & Yes & - & - & - & - \\
\hline 12 & M & 64 & 6 & Yes & Yes & 6 & 4 & Yes & - & - & - & - \\
\hline 13 & $\mathrm{~F}$ & 57 & 6 & Yes & Yes & 7 & 3 & Yes & - & - & - & - \\
\hline 14 & $\mathrm{~F}$ & 60 & 6 & Yes & Yes & 5 & 3 & Yes & - & - & Yes & - \\
\hline 15 & $\mathrm{M}$ & 64 & 6 & Yes & Yes & 6 & 4 & - & Yes & Yes & Yes & Yes \\
\hline 16 & $\mathrm{M}$ & 51 & 6 & Yes & Yes & 8 & 3 & - & Yes & Yes & Yes & Yes \\
\hline 17 & $\mathrm{M}$ & 62 & 6 & Yes & Yes & 4 & 3 & - & Yes & Yes & Yes & Yes \\
\hline 18 & $\mathrm{M}$ & 49 & 6 & Yes & Yes & 7 & 4 & - & Yes & Yes & Yes & Yes \\
\hline 19 & $\mathrm{M}$ & 58 & 6 & Yes & Yes & 8 & 4 & - & Yes & Yes & Yes & Yes \\
\hline 20 & $\mathrm{~F}$ & 63 & 6 & Yes & Yes & 6 & 2 & - & Yes & Yes & Yes & Yes \\
\hline 21 & $\mathrm{M}$ & 66 & 6 & Yes & Yes & 7 & 3 & - & Yes & Yes & Yes & Yes \\
\hline 22 & $\mathrm{~F}$ & 56 & 6 & Yes & Yes & 5 & 4 & - & Yes & Yes & Yes & Yes \\
\hline 23 & $\mathrm{M}$ & 51 & 6 & Yes & Yes & 6 & 3 & - & - & - & - & - \\
\hline
\end{tabular}

M, male; F, female; H\&E, hematoxylin and eosin staining; SMCM, smooth muscle cell medium; 10\%-F12, DMEM/F-12 containing 10\% newborn bovine serum; IHC, immunohistochemical staining; IF, immunofluorescence; RT-qPCR, reverse transcription-quantitative PCR.

were observed with long pseudopods. Many nonadherent or unstretched cells remained floating in the medium at 2 days before flushing (Fig. 1A).

In 6 patients, primary cells isolated from six types of smooth muscles did not adhere to the bottom of 6-well plates, leading to cell counts of 0 . There was no statistical difference in Cells/200x between groups 0.5-EI-4 and 1-EI-4 $(\mathrm{P}=0.994)$, but Cells/200x of groups 0.5-EI-4 and 1-EI-4 were greater than those of the other four groups $(\mathrm{P}<0.001, \mathrm{P}=0.009, \mathrm{P}<0.001$ and $\mathrm{P}<0.001$ for 0.5-EI-4 compared with 1-C-37, 0.5-C-4,0.25-T-37 and 0.125-T-4, respectively; $\mathrm{P}<0.001, \mathrm{P}=0.004, \mathrm{P}<0.001$ and $\mathrm{P}<0.001$ for $1-\mathrm{EI}-4$ compared with $1-\mathrm{C}-37,0.5-\mathrm{C}-4,0.25-\mathrm{T}-37$ and $0.125-\mathrm{T}-4$, respectively). FPD was significantly earlier in 0.5-EI-4 compared with the other five groups $(\mathrm{P}=0.024$, $\mathrm{P}<0.001, \mathrm{P}<0.001, \mathrm{P}<0.001$ and $\mathrm{P}<0.001$ for 0.5 -EI- 4 compared with 1-EI-4, 1-C-37, 0.5-C-4, 0.25-T-37 and 0.125-T-4, respectively), and it was earlier in 1-EI-4 compared with 1-C-37, 0.5-C-4, 0.25-T-37 and 0.125-T-4 ( $\mathrm{P}<0.001, \mathrm{P}<0.001, \mathrm{P}<0.001$ and $\mathrm{P}<0.001$, respectively; Fig. 1B; Table IV). Therefore, it was effective to use a single enzyme to isolate primary cells, both for collagenase II, the most commonly used tool for primary cell isolation, and for Trypsin/EDTA, the most commonly used digestive enzyme in the laboratory. The most efficient ED method in the present study was EI digested with collagenase II at low temperature $\left(4^{\circ} \mathrm{C}\right)$ and low concentration $(0.5 \mathrm{mg} / \mathrm{ml})$ for an extended period (14-24 h). According to these results, 0.5 -EI-4 was the most effective method and cells obtained from 0.5 -EI-4 were used in the subsequent studies.

Growth and proliferation of cells. Cultured cells could be dispersed with $0.25 \%$ Trypsin/EDTA in 40-100 sec at room temperature, then sub-cultured in two flasks, so that the spindle cells were relatively sparse, leaving space between them for cell proliferation (Fig. 2A-a). The primary cells could grow and proliferate in SMCM, but merely survived in 10\%-F12. The proliferation test $(\mathrm{n}=7)$ showed typical ' $\mathrm{S}$-shaped curves' in SMCM, but not in 10\%-F12 (Fig. 2A-b).

Cells cultured in vitro grew in a uniform direction with 'hills and valleys' morphology (Fig. 2B-a). Different morphological types could coexist in cultures obtained from the same tissue. Dominant cells were spindle- or long-spindle-shaped; some were rod-like or besom-like, and pseudopods differed among cells (Fig. 2B-b). As the number of passages increased, cells would gradually enlarge and deform from spindle-like to irregular morphology (Fig. 2B-c). In the first generation, the crowded cells were spherical multicellular nodules, surrounded in a layered fashion. Cells cultured in SMCM lost spindle-like morphology in the fourth to eighth generations [the median 
Table IV. Statistics regarding enzymatic dispersion with tissue blocks of smooth muscle specimens.

\begin{tabular}{|c|c|c|c|c|c|c|c|c|}
\hline \multirow[b]{2}{*}{ Group } & \multicolumn{4}{|c|}{ Cells/x200 } & \multicolumn{4}{|c|}{ FPD } \\
\hline & $\mathrm{n}$ & Median & Interquartile range & Range & $\mathrm{n}$ & Mean & Standard deviation & Range \\
\hline $0.5-\mathrm{EI}-4$ & 85 & 73.00 & 63.00 & $0-170$ & 81 & 9.01 & 3.15 & $5-19$ \\
\hline 1-EI-4 & 98 & 66.00 & 50.00 & $0-160$ & 95 & $10.27^{\mathrm{a}}$ & 3.09 & $6-20$ \\
\hline $1-C-37$ & 132 & $38.50^{\mathrm{a}, \mathrm{b}}$ & 46.00 & $0-167$ & 123 & $14.35^{\mathrm{a}, \mathrm{b}}$ & 4.18 & $6-23$ \\
\hline $0.5-\mathrm{C}-4$ & 78 & $43.50^{\mathrm{a}, \mathrm{b}}$ & 42.00 & $0-182$ & 75 & $14.04^{\mathrm{a}, \mathrm{b}}$ & 3.68 & $7-24$ \\
\hline $0.25-\mathrm{T}-37$ & 82 & $31.50^{\mathrm{a}, \mathrm{b}}$ & 34.00 & $0-164$ & 80 & $15.95^{\mathrm{a}-\mathrm{d}}$ & 4.16 & $6-26$ \\
\hline $0.125-\mathrm{T}-4$ & 67 & $34.00^{\mathrm{a}, \mathrm{b}}$ & 25.00 & $0-124$ & 66 & $15.23^{\mathrm{a}, \mathrm{b}}$ & 3.45 & $6-26$ \\
\hline
\end{tabular}

${ }^{\mathrm{a}} \mathrm{P}<0.05$ vs. 0.5 -EI-4; ${ }^{\mathrm{b}} \mathrm{P}<0.05$ vs. 1 -EI- 4 ; ${ }^{\mathrm{C}} \mathrm{P}<0.05$ vs. $1-\mathrm{C}-37$; ${ }^{\mathrm{d}} \mathrm{P}<0.05$ vs. $0.5-\mathrm{C}-4$. Cells/x200, number of visible adherent cells per field of microscope (magnification, $\mathrm{x} 200$ ).FPD, time required for primary cell growth to the first passage day; $\mathrm{n}$, number of smooth muscle fragments; EI, enzyme injection; C, collagenase II; T, Trypsin; 0.5 -EI-4, $0.5 \mathrm{mg} / \mathrm{ml}$ collagenase II solution injected into tissues at $4^{\circ} \mathrm{C} ; 1$-EI-4, $1 \mathrm{mg} / \mathrm{ml}$ collagenase II solution injected into the tissues at $4^{\circ} \mathrm{C} ; 1-\mathrm{C}-37$, digested at $37^{\circ} \mathrm{C}$ with $1 \mathrm{mg} / \mathrm{ml}$ collagenase II solution; 0.5-C-4, digested at $4^{\circ} \mathrm{C}$ with $0.5 \mathrm{mg} / \mathrm{ml}$ collagenase II solution; 0.25 -T-37, digested at $37^{\circ} \mathrm{C}$ with $0.25 \%$ Trypsin/EDTA; $0.125-\mathrm{T}-4$, digested at $4{ }^{\circ} \mathrm{C}$ with $0.125 \%$ Trypsin/EDTA.
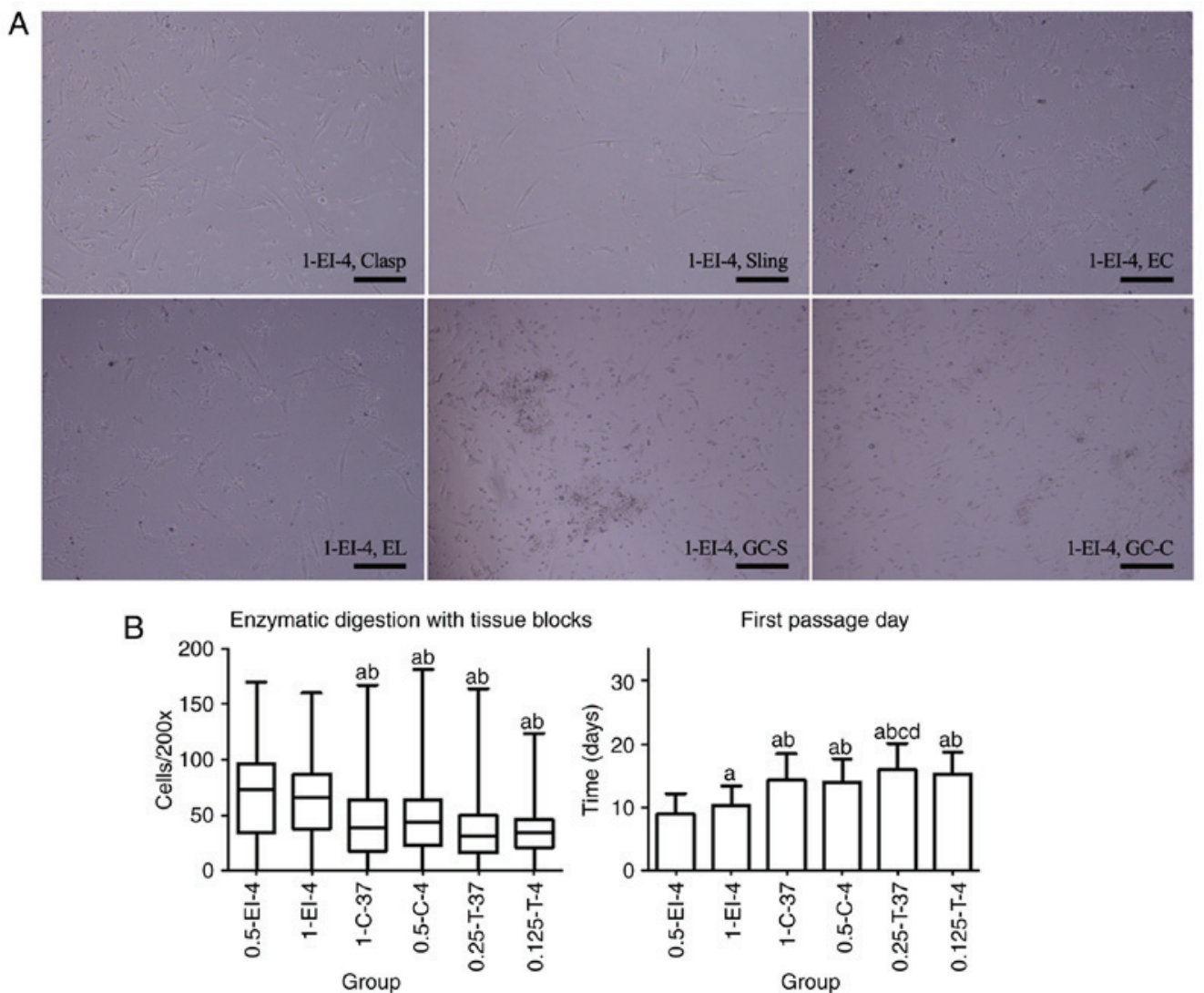

Figure 1. Primary cells of esophagogastric junction obtained by ED. (A) Primary cells obtained by 1-EI-4 as an example after $36 \mathrm{~h}$ of adherence. Cells showed equal background distribution and scattered cell fragments after adherence. Most cells were spindle- or long-spindle-shaped but not uniform as some were rod-like. Few fibroblasts could be seen with long pseudopods. Magnification, x200; scale bar, $200 \mu \mathrm{m}$. (B) Comparison of different ED methods to obtain primary cells (from 23 patients). There were no statistical differences in visible adherent cells per field of microscope (magnification, x200; Cells/200x); 0.5 -EI-4 was statistically different from both $0.5-\mathrm{C}-4$ and 0.25 -T-37 in the first passage day. ${ }^{a} \mathrm{P}<0.05$ vs. 0.5 -EI-4; ${ }^{b} \mathrm{P}<0.05$ vs. 1 -EI- 4 ; ${ }^{\mathrm{c}} \mathrm{P}<0.05$ vs. $1-\mathrm{C}-37$; ${ }^{\mathrm{d}} \mathrm{P}<0.05$ vs. 0.5-C-4. ED, enzymatic dispersion. Clasp, clasp fiber; Sling, sling fiber; EC, esophageal circular; EL, esophageal longitudinal; GC-S, gastric circular muscle near sling in gastric bottom; GC-C, gastric circular muscle near clasp in lesser gastric curvature; EI, enzyme injection; C, collagenase II; T, Trypsin; 0.5 -EI- $4,0.5 \mathrm{mg} / \mathrm{ml}$ collagenase II solution injected into tissues at $4^{\circ} \mathrm{C} ; 1$-EI- $4,1 \mathrm{mg} / \mathrm{ml}$ collagenase II solution injected into the tissues at $4^{\circ} \mathrm{C}$; 1-C-37, digested at $37^{\circ} \mathrm{C}$ with $1 \mathrm{mg} / \mathrm{ml}$ collagenase II solution; $0.5-\mathrm{C}-4$, digested at $4^{\circ} \mathrm{C}$ with $0.5 \mathrm{mg} / \mathrm{ml}$ collagenase II solution; $0.25-\mathrm{T}-37$, digested at $37^{\circ} \mathrm{C}$ with $0.25 \%$ Trypsin/EDTA; $0.125-\mathrm{T}-4$, digested at $4^{\circ} \mathrm{C}$ with $0.125 \%$ Trypsin/EDTA.

number of cell passages (interquartile range) was $6.0(2.0)$ generations and the maximum and minimum values were at generations 8 and 4 , respectively]; this change occurred in the second to fourth generations of $10 \%-\mathrm{F} 12$ cultures [the median 


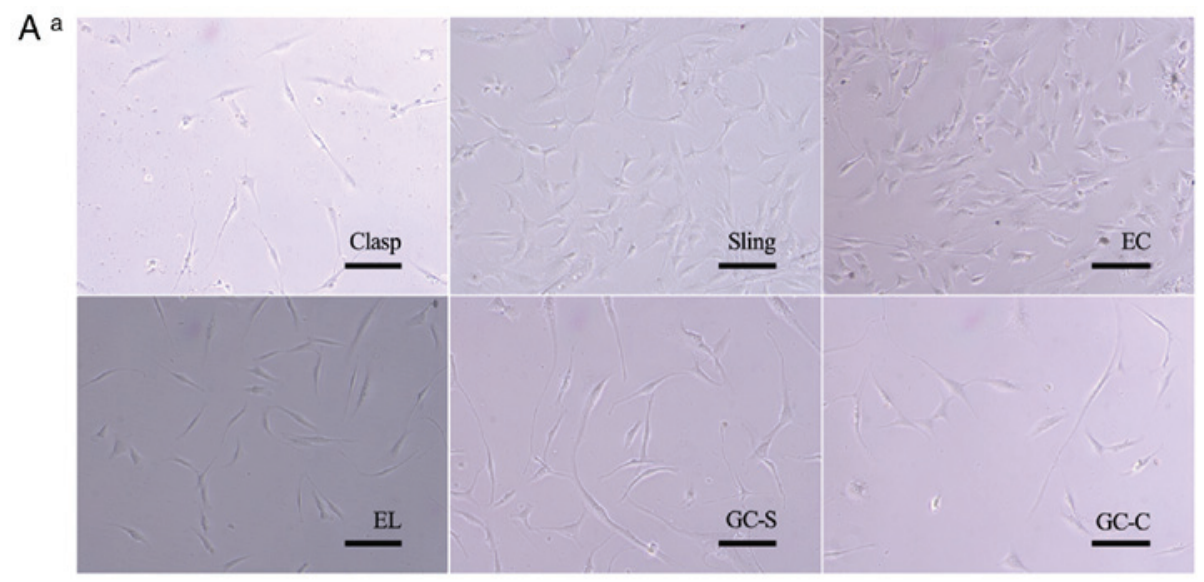

b

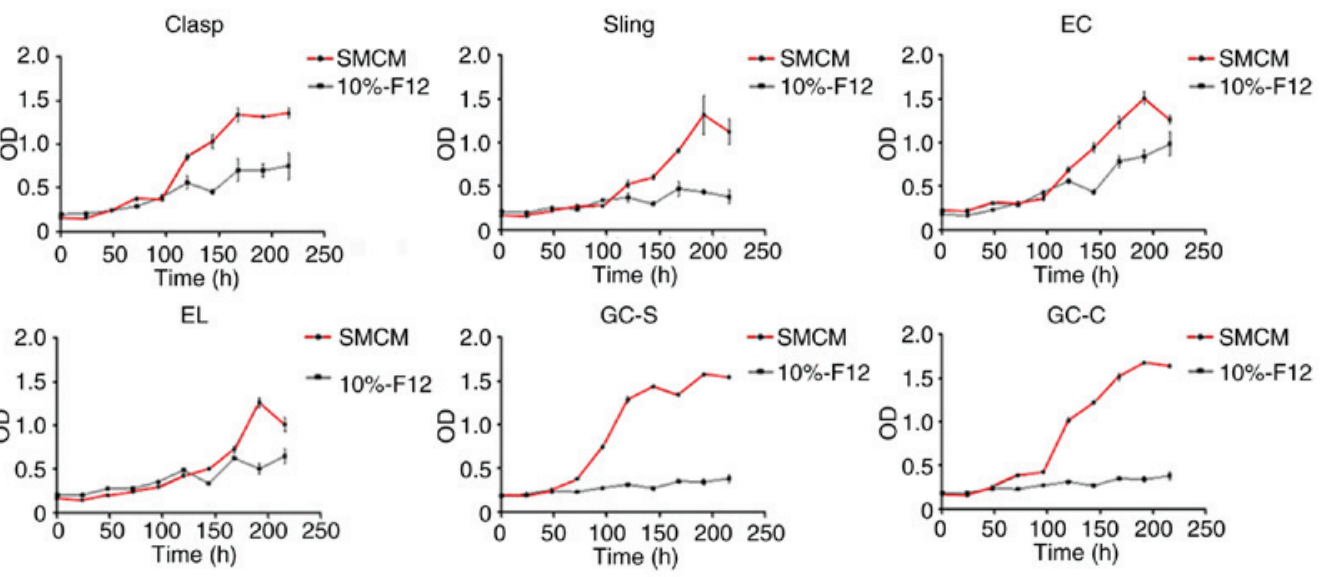

B

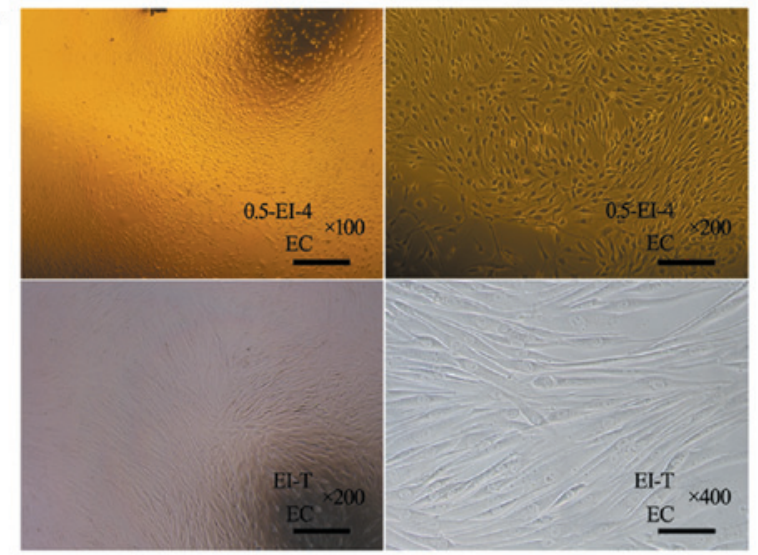

b

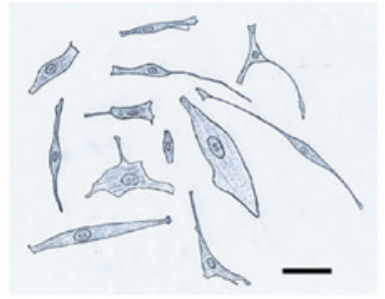

c

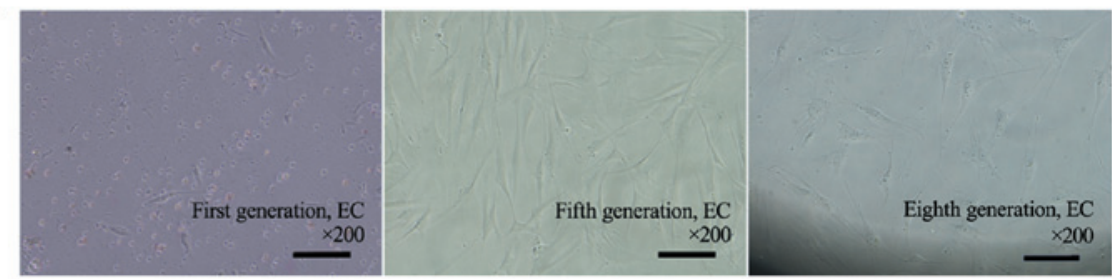

Figure 2. Growth and proliferation of esophagogastric junction cells in vitro. (A) Cells obtained by EI in sub-culture. (A-a) Cell morphology of each group after sub-culture to the third generation. Magnification, x200; scale bar, $200 \mu \mathrm{m}$. (A-b) Cell proliferation curves in SMCM (third generation; red curve) and DMEM/F12 containing $10 \%$ newborn bovine serum (10\%-F12; second generation; black curve). $\mathrm{n}=7$. Experiments were perfomed in duplicate. A typical 'S' curve was observed in SMCM; in 10\%-F12, cell proliferation was largely stopped. (B) Representative cell morphology of EC muscle cells. (B-a) Typical structure of 'hills and valleys' for primary (two images above on 10th day after adherence) and sub-cultured (two images below, second generation) cells obtained by EI. Scale bar, $200 \mu \mathrm{m}$. Cells cultured in vitro grew in a uniform direction as 'hills and valleys', as determined by in topographical mapping. (B-b) An illustration of cell morphology. Magnification, x400; scale bar, $200 \mu \mathrm{m}$. Cells were spindle- or long-spindle-shaped, but not uniform; some were rod- or besom-like. Pseudopods of cells differed. (B-c) As the number of passages increased, spindle cells became larger and deformed. Magnification, x200; scale bar, $200 \mu \mathrm{m}$. Sizes and morphologies of the fifth (middle) and eighth (right) generation cells were compared with primary spindle cells (left), after $36 \mathrm{~h}$ of adherence. EI, enzyme-injected; SMCM, smooth muscle cell medium; Clasp, clasp fiber; Sling, sling fiber; EC, esophageal circular; EL, esophageal longitudinal; GC-S, gastric circular muscle near sling in gastric bottom; GC-C, gastric circular muscle near clasp in lesser gastric curvature; OD, optical density; 0.5 -EI- $4,0.5 \mathrm{mg} / \mathrm{ml}$ collagenase II solution injected into tissues at $4^{\circ} \mathrm{C} ; 1-\mathrm{EI}-4,1 \mathrm{mg} / \mathrm{ml}$ collagenase II solution injected into the tissues at $4{ }^{\circ} \mathrm{C} ; \mathrm{T}$, Trypsin. 
A
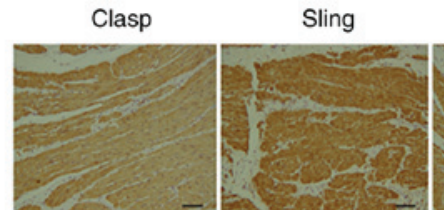

EC

EL

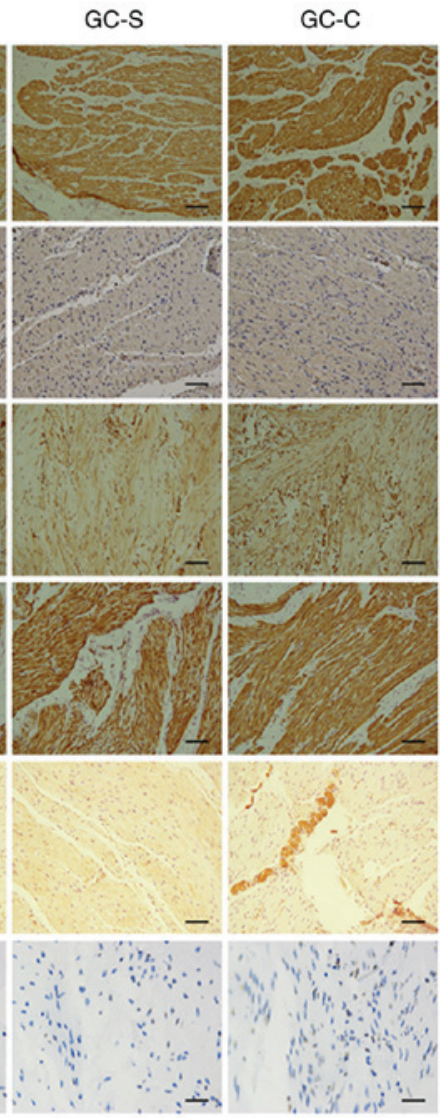

PCNA
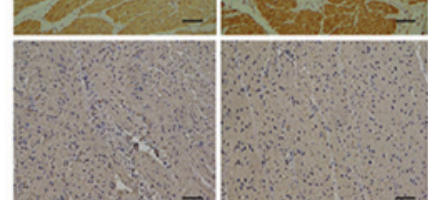

Vimentin
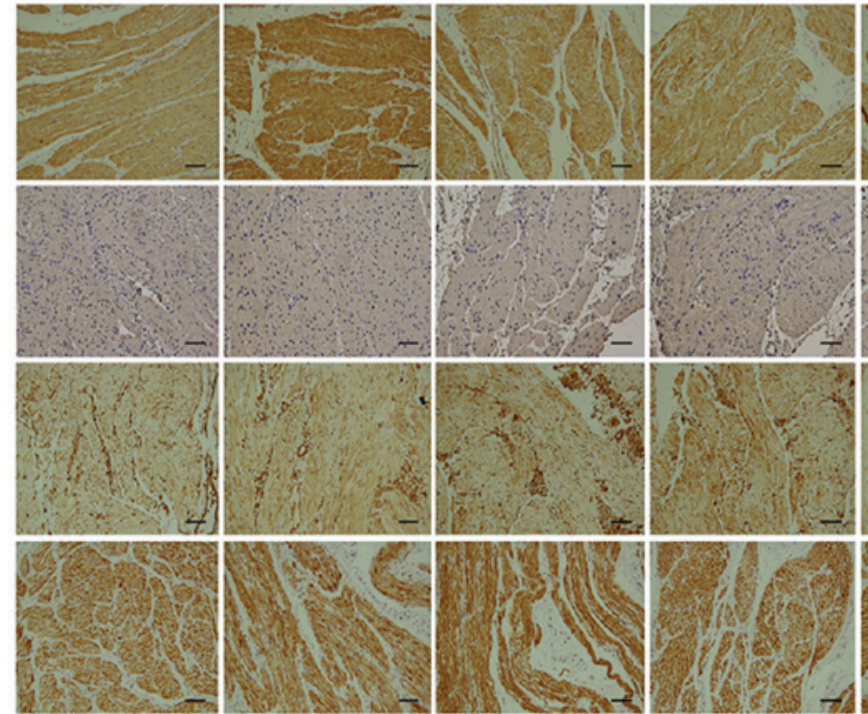

CD90

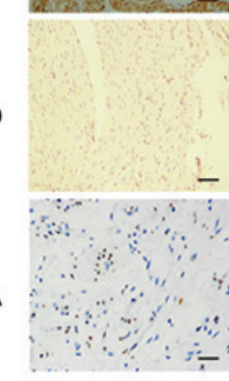

B
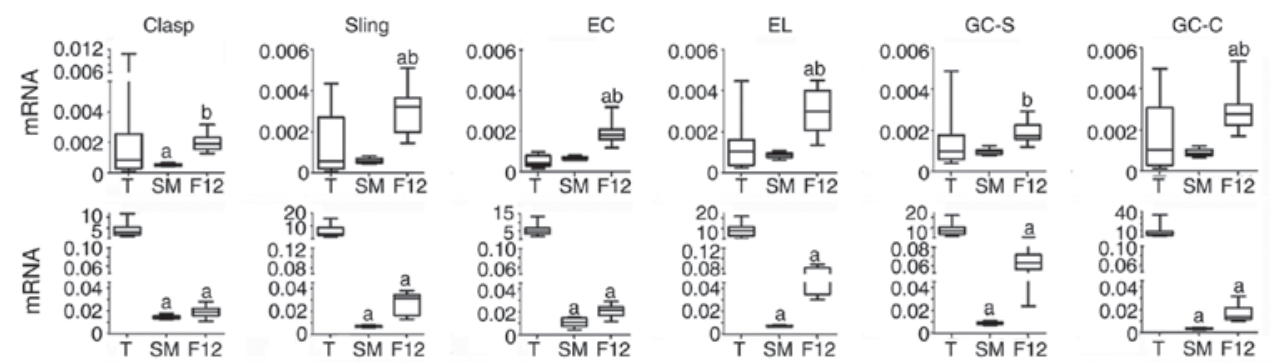

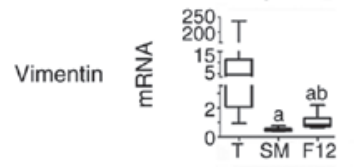

${ }_{10}^{30}$

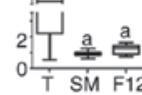
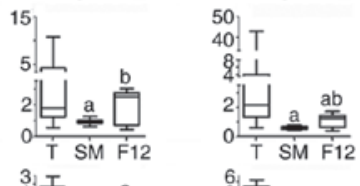

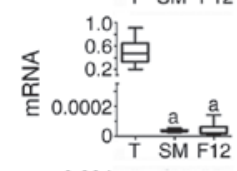

3.

Desmin

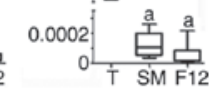
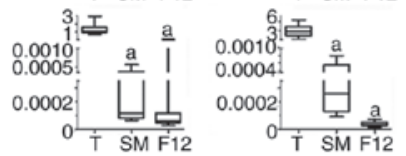

30. ${ }^{30}$.

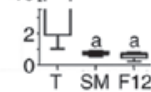

8. I

2보놀

2.

0.0002
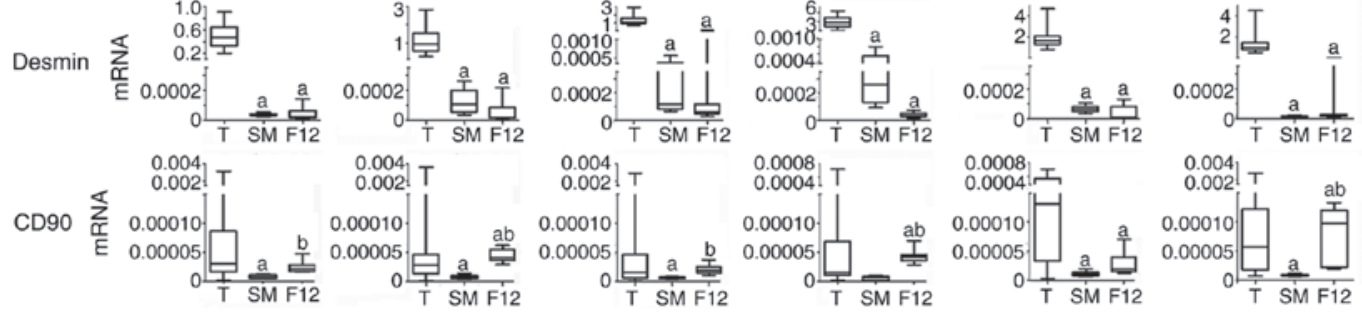

$\left.\begin{array}{l}0.004 \\ 0.002\end{array}\right]$

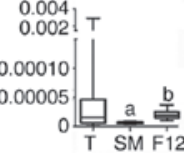

0.0008
0.0004
0.00010 0.0000

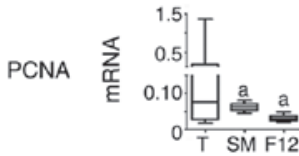
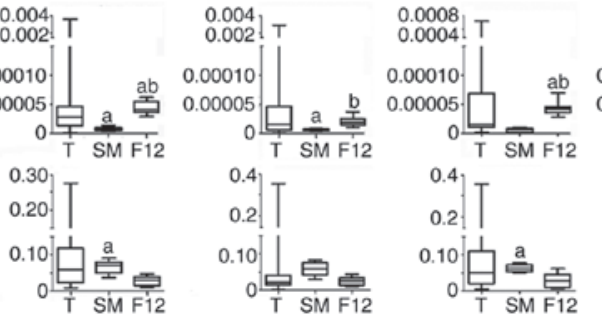

0.0008 . 0.5
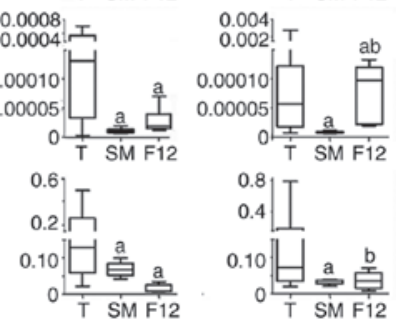

Figure 3. Expression of smooth muscle markers and PCNA in human EGJ. (A) Immunohistochemical staining (IHC) of EGJ smooth muscles using the streptavidin-peroxidase method. $n=8$. Experiments were performed in duplicate. Positive expression of $\alpha$-SMA, SM22 $\alpha$, vimentin, desmin, CD90 and PCNA was observed in six types of smooth muscles. Scale bar, $200 \mu \mathrm{m}$. $\alpha$-SMA, vimentin, desmin were strong or moderate in the cytoplasm (magnification, 200 ); however, SM22 $\alpha$ was moderate or weak in the cytoplasm (magnification, x200). CD90 was moderate or weak in the cytomembrane and cytoplasm (magnification, x200); PCNA was strong or moderate in part of the nucleus (magnification, $\mathrm{x} 400$ ). In addition, vimentin and CD90 were stronger in the small vascular walls of smooth muscles. (B) Relative mRNA expression of smooth muscle markers and PCNA in EGJ smooth muscle tissues and cells. $\mathrm{n}=8$. Experiments were performed in triplicate. ${ }^{a} \mathrm{P}<0.05$ vs. T; ${ }^{b} \mathrm{P}<0.05$ vs. SM. PCNA, proliferating cell nuclear antigen; EGJ, esophagogastric junction; Clasp, clasp fiber; Sling, sling fiber; EC, esophageal circular; EL, esophageal longitudinal; GC-S, gastric circular muscle near sling in gastric bottom; GC-C, gastric circular muscle near clasp in lesser gastric curvature; $\alpha$-SMA, $\alpha$-smooth muscle actin; SM22 $\alpha$, smooth muscle $22 \alpha$; T, tissue; SM, cells cultured in smooth muscle cell medium; F12, cells cultured in DMEM/F12 containing 10\% newborn bovine serum. 
Table V. IHC scores of marker staining in smooth muscles of the esophagogastric junction.

\begin{tabular}{|c|c|c|c|c|c|c|}
\hline Name & $\alpha-\mathrm{SMA}$ & SM22 $\alpha$ & Vimentin & Desmin & CD90 & PCNA \\
\hline Clasp & $10.0(1.0)$ & $4.0(1.0)$ & $9.0(1.0)$ & $11.0(1.0)$ & $3.0(1.1)$ & $9.0(1.0)$ \\
\hline Sling & $10.0(1.0)$ & $3.9(1.0)$ & $9.2(1.0)$ & $11.0(1.0)$ & $3.0(1.0)$ & $9.0(1.0)$ \\
\hline $\mathrm{EC}$ & $10.0(1.0)$ & $4.0(1.1)$ & $9.0(1.0)$ & $11.0(1.0)$ & $3.1(1.0)$ & $9.0(1.0)$ \\
\hline EL & $10.0(1.0)$ & $3.5(1.0)$ & $9.0(1.0)$ & $11.0(1.0)$ & $3.0(1.0)$ & $8.9(1.0)$ \\
\hline GC-S & $10.0(1.0)$ & $4.0(1.0)$ & $8.9(1.0)$ & $11.0(1.0)$ & $3.0(1.0)$ & $9.1(0.8)$ \\
\hline GC-C & $10.0(1.0)$ & $4.0(1.0)$ & $9.0(1.0)$ & $11.0(1.0)$ & $3.0(1.0)$ & $8.9(1.0)$ \\
\hline
\end{tabular}

Data are presented as the median (interquartile range). $n=8 . \alpha$-SMA, $\alpha$-smooth muscle actin; SM22 $\alpha$, smooth muscle $22 \alpha$; PCNA, proliferating cell nuclear antigen; Clasp, clasp fiber; Sling, sling fiber; EC, esophageal circular; EL, esophageal longitudinal; GC-S, gastric circular muscle near sling in gastric bottom; GC-C, gastric circular muscle near clasp in lesser gastric curvature.

number of cell passages (interquartile range) was 3.0 (1.0) generations and the maximum and minimum values were at generations 4 and 2, respectively] (Table III). Cryopreservation was feasible in a combination of NBS and DMSO (volume ratio, 9:1) in the following processes: $4^{\circ} \mathrm{C}$ for $30 \mathrm{~min} \rightarrow-20^{\circ} \mathrm{C}$ for $2-4 \mathrm{~h} \rightarrow-80^{\circ} \mathrm{C}$ for $3-4$ months), but most cells died if the duration exceeded 6 months at $-80^{\circ} \mathrm{C}$.

In the present study, it was observed that specimens from older donors (65-71 years) yielded fewer SMCs; it was more difficult to obtain enough cells from their tissues. Despite the success of primary culture, such cells showed more rapid aging and deformation, and could tolerate fewer passages. Conversely, tissues provided by younger donors (49-56 years) yielded SMCs relatively easily; these were also easy to culture and passage.

Identification of SMCs. IHC of smooth muscle markers and PCNA in EGJ smooth muscles was performed. In paraffin sections of six types of EGJ smooth muscles, positive staining was observed for $\alpha$-SMA, SM22 $\alpha$, vimentin, desmin, CD90 and PCNA (Fig. 3A; Table V; $n=8$ ). $\alpha$-SMA, vimentin and desmin staining was strong or moderate in the cytoplasm; SM22 $\alpha$ staining was moderate or weak in the cytoplasm. CD90 staining was moderate or weak in cytomembrane and cytoplasm; PCNA staining was strong or moderate in the nucleus.

mRNA expression of smooth muscle markers and PCNA. By using automatic plotting of dissolution and amplification curves in ABI 7500 , mRNA of $\alpha$-SMA, SM22 $\alpha$, vimentin, desmin, CD90 and PCNA could be detected in EGJ smooth muscles and cells (Fig. 3B and Table VI; $n=8$ ). Each cell type showed different levels of mRNA expression in different types of medium. SM22 $\alpha$ and desmin mRNA levels in cells were lower than in the corresponding tissues; however, $\alpha$-SMA, vimentin, CD90 and PCNA varied in comparison with the corresponding tissues.

Immunofluorescence of smooth muscle markers and PCNA. Immunofluorescence observation was performed in cells obtained by ED (SMCS) $(n=9)$. The same target was identified at different wavelengths because primary antibodies were from different species. Positive expression of $\alpha$-SMA, SM22 $\alpha$, vimentin, CD90 and PCNA was observed in cells; desmin was weak or negative (Fig. 4). GAPDH and PCNA could be detected in the cytoplasm and nucleus.

Protein expression of smooth muscle markers and PCNA. Expression of $\alpha$-SMA, SM22 $\alpha$, vimentin, desmin, CD90 and PCNA in cells obtained by ED could be detected by the in-cell western assay (Fig. 5 and Table VII; $n=8$ ). Relative expression of $\alpha$-SMA, SM22 $\alpha$ and vimentin in cells obtained by ED (10\%-F12) appeared greater than that of ED (SMCM); only EC, EL, GC-S and GC-C demonstrated statistical differences in SM22 $\alpha$ and vimentin. CD90 expression in cells obtained by ED (SMCM) was greater than in ED (10\%-F12). The relative expression of desmin was low in cells. There was no statistical difference in PCNA between ED (SMCM) and ED (10\%-F12) cells. Trends of relative mRNA and corresponding protein expression in cells were similar, with the exception of CD90, where. CD90 protein in ED (10\%-F12) cells was markedly lower compared with in ED (SMCM. This is, in contrast to mRNA expression trends observed.

\section{Discussion}

It was previously identified that SMCs are not terminally differentiated cells [from a previous studyof vascular SMCs (VSMCs) (32)]; synthetic (secretory) and contractile SMCs have been demonstrated to be in a dynamic balance (17). ED and explant culture methods are widely used in SMC culture in vitro, but cells from ED represent the entire breadth of SMC phenotypes. Therefore, many relative experimental projects can be performed with superior representativeness; moreover, the time for acquisition of cells in ED is shorter than in the explant culture method (24 h vs. 2-3 weeks) (1). These details are not clear in SMC culture in vitro obtained from the digestive tract, although previous studies have used ED or explant culture with tissue blocks $(4,5,7-9,33)$. Previous studies on motor function of smooth muscles in EGJ have revealed critical factors for physiology and pathophysiology of PEMDs and GERD $(7,12,34)$. Effective isolation methods of primary SMCs and growth characteristics of cultured SMCs should be recorded in detail so that follow-up studies can be performed to resolve current difficulties. The present study is part of research on signal transduction in esophageal smooth muscles 


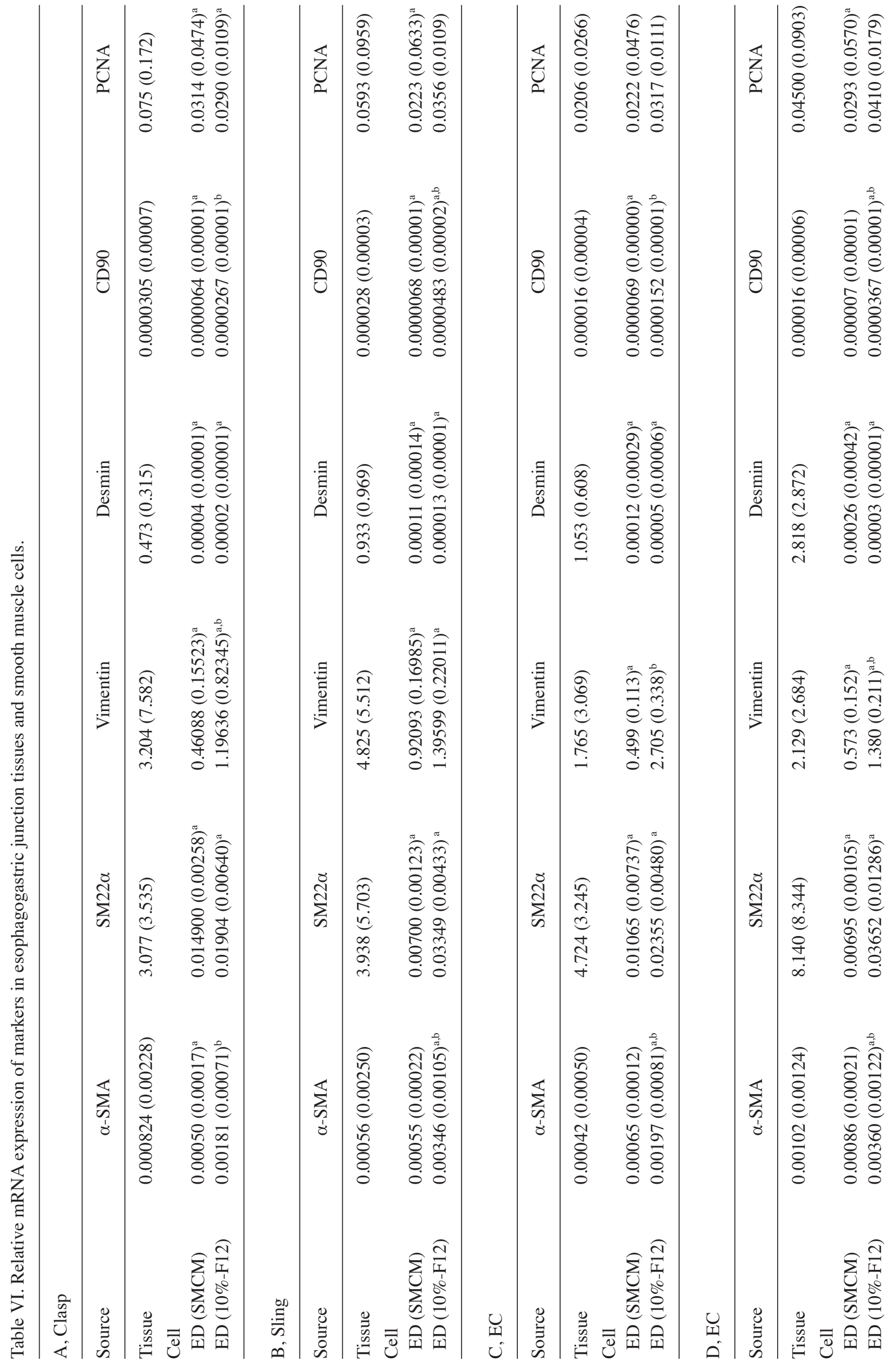




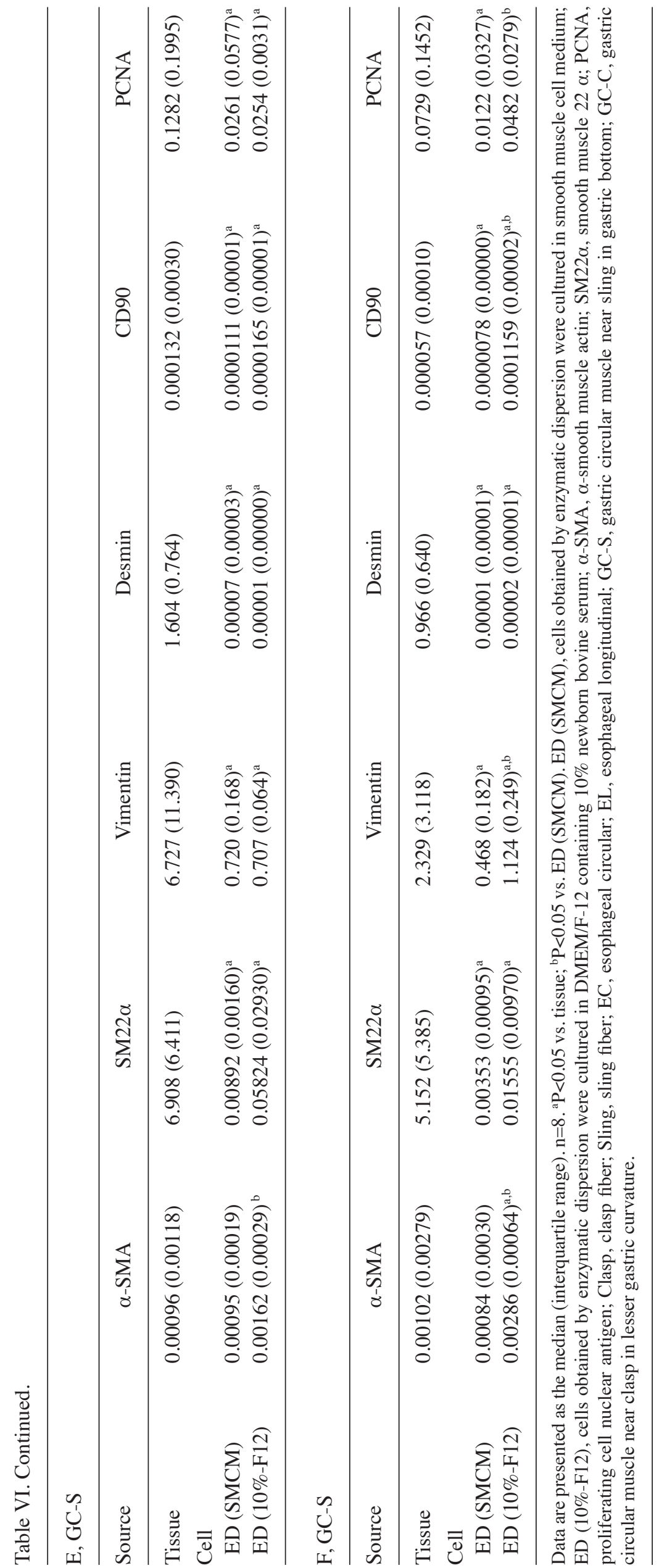




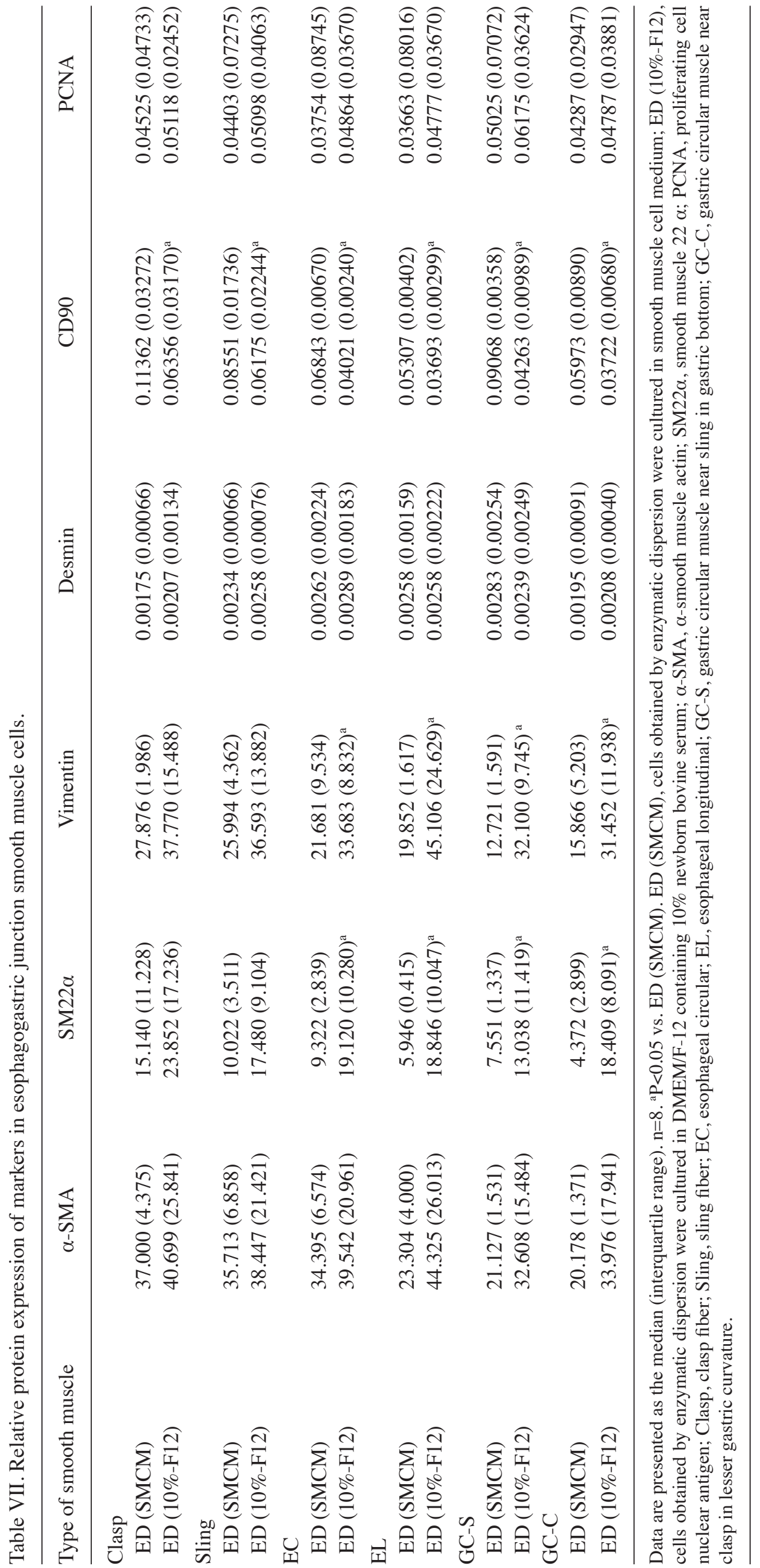



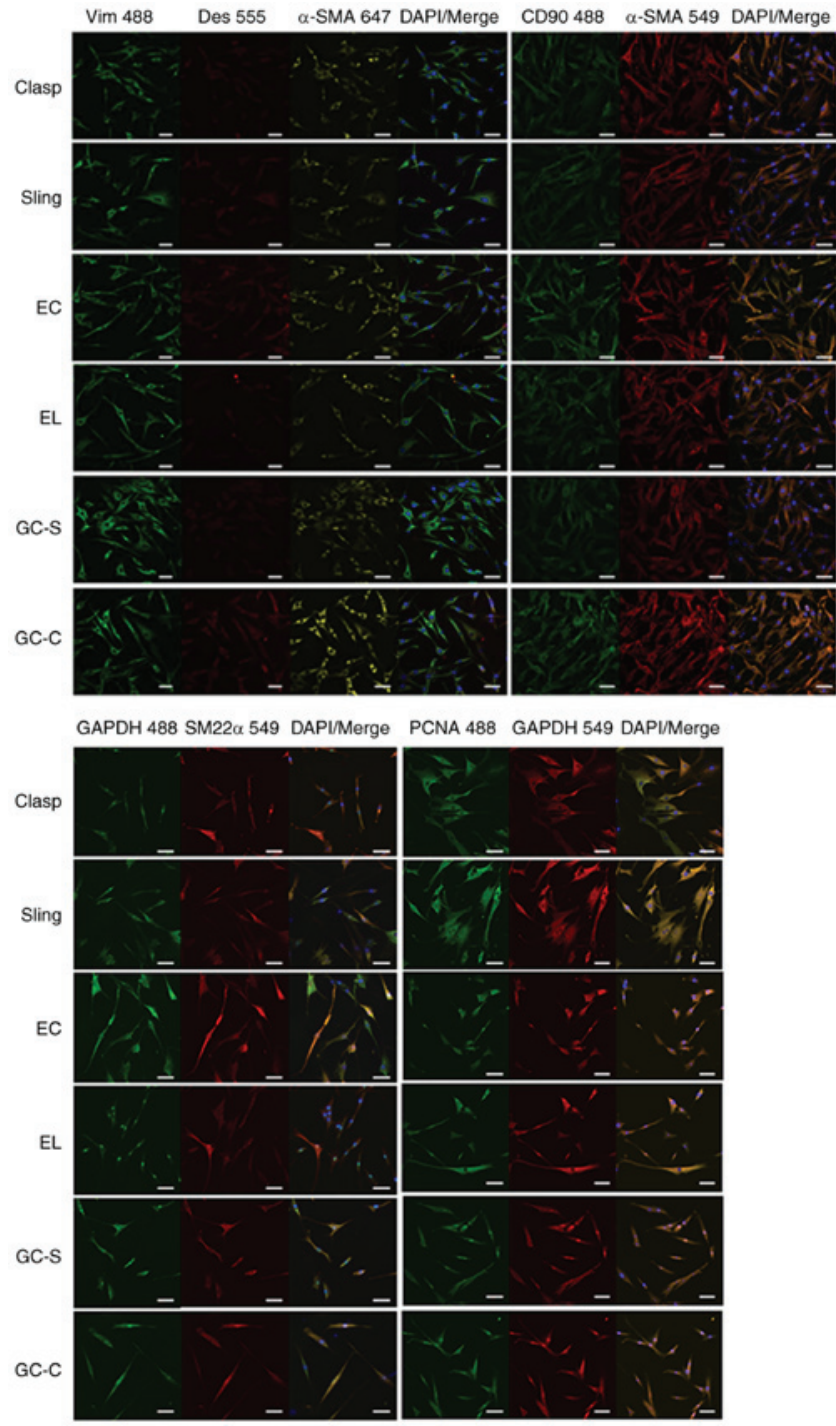

Figure 4. Immunofluorescence (IF) of smooth muscle markers and PCNA for esophagogastric junction cells cultured in vitro by cells obtained by enzymatic dispersion and cultured in SMCM. The third generation of cells cultured in SMCM were tested. $n=9$. Experiments were performed in triplicate. Scale bar, $150 \mu \mathrm{m}$. Primary antibodies were premixed in $2 \%$ BSA-PBS. $\alpha$-SMA, SM22 $\alpha$, Vim, CD90 and PCNA were positive in cells; Des was weak or not visible. Theoretically, CD90 and PCNA are expressed in the cell membrane and nucleus, respectively. However, due to permeabilization of cells with $0.3 \%$ (v/v) Triton X-100 in this experiment, primary antibodies entered cells and resulted in fluorescence of relative proteins, including proteins that were being synthesized and were within functional structures. PCNA, proliferating cell nuclear antigen; SMCM, smooth muscle cell medium; Vim, vimentin; Des, Desmin; $\alpha$-SMA, $\alpha$-smooth muscle actin; SM22 $\alpha$, smooth muscle $22 \alpha$ Clasp, clasp fiber; Sling, sling fiber; EC, esophageal circular; EL, esophageal longitudinal; GC-S, gastric circular muscle near sling in gastric bottom; GC-C, gastric circular muscle near clasp in lesser gastric curvature.

of achalasia. On the basis of the present study, follow-up function and model experiments can be carried out (34).

In previous studies of SMCs obtained by ED, investigators typically used two or more types of enzymes, including collagenase type I (9), type II $(3,8,11,13)$, type V (10), type VIII (35) and type XI (7), co-digested with elastase $(9,13)$, papain $(10,13)$, deoxyribonuclease I $(8,11)$, dispase $(7,9)$ or trypsin inhibitor (Soybean) $(19,36)$ in one or two steps. The temperature used was typically $37^{\circ} \mathrm{C}$ because it was the optimum temperature for enzyme activity. Collagenase II is one of the most commonly used enzymes for isolation of primary SMCs, and immersion of tissue fragments directly in collagenase II solution constitutes the most common isolation method. Detailed usage of collagenase II in primary cell isolation was the main objective of the present study.

In the present study, collagenase II and Trypsin/EDTA were selected, as they are commonly used in cell culture, to determine a simple and effective isolation method. There were six groups: 0.5 -EI-4 and 1-EI-4 were the experimental groups in which the new isolation methods were used, and 1-C-37 and 0.5-C-4 were the groups in which traditional ED were used; the 0.25-T-37 and 0.125-T-4 groups were included to test whether Trypsin/EDTA could also be used for effective isolation of SMCs. The present results demonstrated that adherent cells could be obtained by different ED methods, but the time required for FPD differed among these methods. The most effective method was EI with low collagenase II concentration $(0.5 \mathrm{mg} / \mathrm{ml})$ combined with a low temperature $\left(4^{\circ} \mathrm{C}\right)$ for $14-24 \mathrm{~h}$. Collagenase is mainly used to hydrolyze collagen protein in connective tissue. In practice, a high concentration of collagenase, extended digestion time, or digestion at $37^{\circ} \mathrm{C}$ could lead to prolonged FPD in a single enzyme process, likely due to damage of cellular structures. This combination of low enzyme concentration with low temperature for an extended digestion time reduced enzyme damage to cells. Furthermore, Trypsin/EDTA could also be used for SMC isolation. Trypsin/EDTA is one of the most commonly used and inexpensive reagents in cell culture. Notably, Trypsin/EDTA is not a conventional enzyme for isolating primary SMCs $(37,38)$. The Trypsin/EDTA group was included in the present study to demonstrate that Trypsin/EDTA could be used as a tool for isolation of SMCs, in order to increase the choices available for a variety of experimental conditions. There are many alternative digestive enzymes for isolation of SMCs, and many potential combinations for experimental grouping designs. The Trypsin/EDTA method yielded fewer adherent cells with slower rates of cell growth and passage; thus, a group that used Trypsin/EDTA with the injection method was not included.

SMCM is mainly comprised DMEM containing 10\% FBS (7,11,39) with P/S (11,39). RPMI 1640 (13) and SMCM $(14,35,40)$ can also be used. In the present study, primary cells were cultured in DMEM/F12 containing $10 \%$ NBS (10\%-F12) and patented SMCM; similar morphological features of EGJ cells were observed in a previous study for VSMCs in vitro (1). Cells obtained by ED were not uniform with spindle-, long-spindle, rod-like, or besom-like shapes; however, they exhibited 'hills and valleys' growth. The CCK-8 assay identified a typical ' $S$ ' curve for proliferation in SMCM, but a lack of proliferation in 10\%-F12. The patented SMCM contains $2 \% \mathrm{FBS}, 1 \%$ SMC growth supplement and $1 \% \mathrm{P} / \mathrm{S}$. Media lacking growth factors is not able to promote human cell growth and proliferation in vitro. The content of SMC growth supplement is not disclosed because it is a patented formula. This is the most widely used available medium for SMCs in laboratories (17); many researchers use it because it can effectively promote the growth and proliferation of SMCs, and delay cell differentiation during short-term cell culture experiments. EGJ SMCs cultured in 10\%-F12 showed a marked decrease in cell number after digestion and passage, 

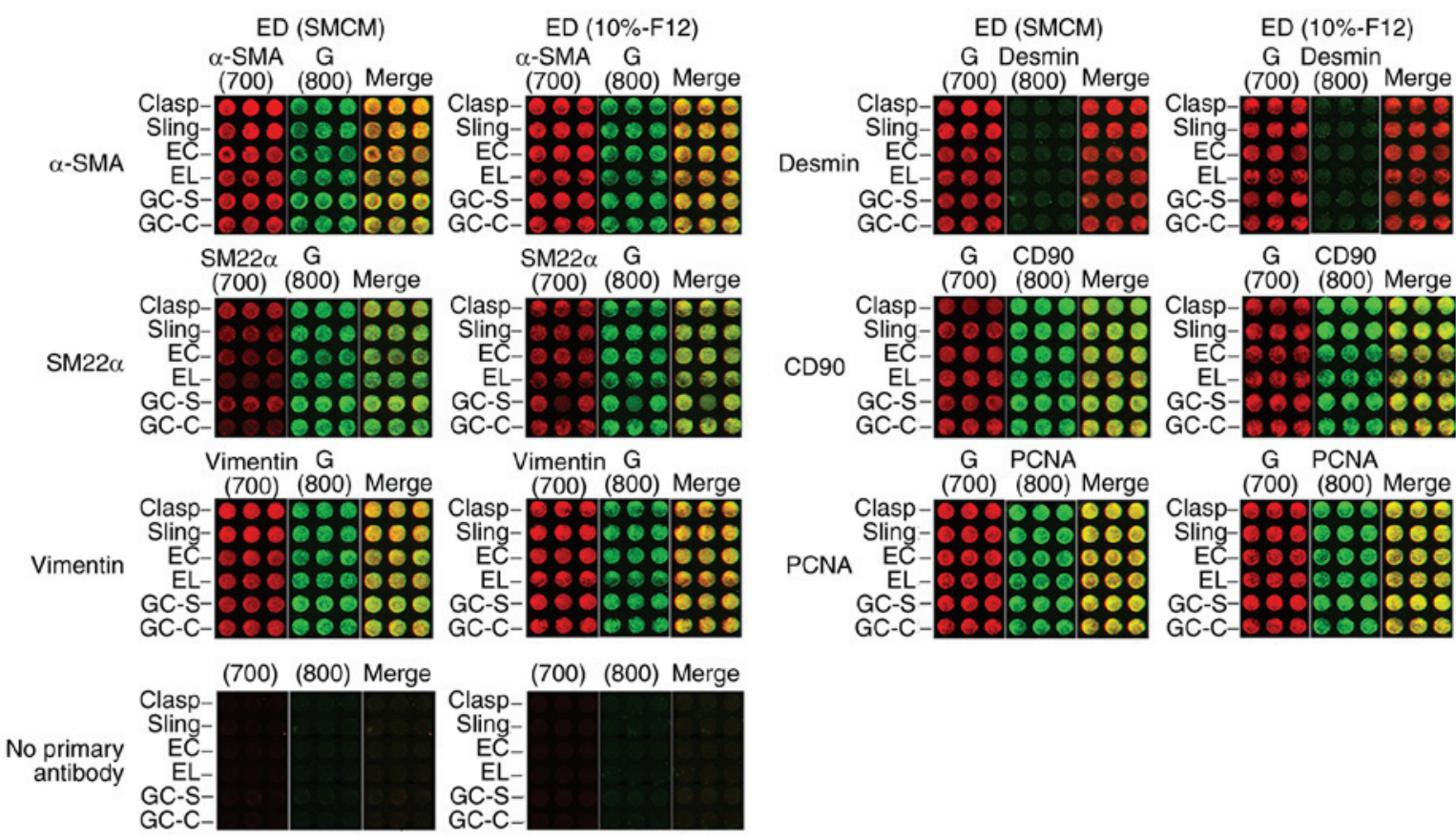

Figure 5. Comparison of fluorescence intensity of smooth muscle markers and PCNA in cultured cells obtained by the ED method. $\mathrm{n}=8$. Experiments were performed in triplicate. Cells were fixed with $4 \%$ paraformaldehyde and permeabilized with $0.3 \%$ (v/v) Triton X-100. After being blocked with 5\% BSA-PBS, cells were incubated with primary antibodies and anti-GAPDH, premixed in $2 \%$ BSA-PBS $\left(12 \mathrm{~h}\right.$ at $\left.4^{\circ} \mathrm{C}\right)$. Concentrations are presented in the immunofluorescence method. $\alpha$-SMA, SM22 $\alpha$, vimentin, desmin, CD90 and PCNA in cells obtained by ED could be detected with different fluorescence intensities. Smooth muscle markers and PCNA of each cell showed different levels of expression, according to culture conditions. PCNA, proliferating cell nuclear antigen; ED, enzymatic dispersion; ED (SMCM), cells obtained by enzymatic dispersion were cultured in smooth muscle cell medium; ED (10\%-F12), cells obtained by enzymatic dispersion were cultured in DMEM/F-12 containing 10\% newborn bovine serum; $\alpha$-SMA, $\alpha$-smooth muscle actin; SM22 $\alpha$, smooth muscle $22 \alpha$; G, GAPDH; Clasp, clasp fiber; Sling, sling fiber; EC, esophageal circular; EL, esophageal longitudinal; GC-S, gastric circular muscle near sling in gastric bottom; GC-C, gastric circular muscle near clasp in lesser gastric curvature.

and nearly all were deformed after 2-4 passages, regardless of exchanging NBS with FBS. Growth factors in bovine serum were insufficient to stimulate the growth and proliferation of human EGJ SMCs in vitro. The main cause for the differences in proliferation between cells grown in the two types of media may be due to their compositions, but the specific factor has not been investigated. Therefore, SMCM is appropriate for use in expanding the cell population, consistent with a previous study by Patel et al (17).

Tissues derived from older donors were observed to not be as conducive to SMC isolation and primary culture, compared with tissues derived from younger donors. Similar results were observed in human arterial SMCs (41) and rat myocardial SMCs (42) cultured in vitro; the growth and proliferative ability of SMCs was inversely proportional to donor age. This might be due to the advanced donor age ( $>60$ years) and a greater degree of differentiation of human tissues in the present study.

Specific markers of SMC subsets in vitro remain unclear $(1,13)$; thus, it is difficult to distinguish contractile and synthetic phenotypes, or to distinguish among other phenotypes of cells from smooth muscles. In the present study, $\alpha$-SMA and SM22 $\alpha$ were selected to identify tissues and cells, along with vimentin, desmin and CD90. $\alpha$-SMA and SM22 $\alpha$ are common specific markers in SMC studies (13-15). Results of IHC, RT-qPCR, immunofluorescence and the in-cell western assay demonstrated that these markers were present in SMCs. Combined with the aforementioned morphological features described, the majority of cells obtained by EI were SMCs. mRNA expression of these markers in cells differed from the expression in corresponding tissues, especially for $\alpha$-SMA, SM22 $\alpha$, desmin and CD90. A previous study identified that esophageal SMCs cultured in vitro had decreased $\alpha$-SMA expression, whereas desmin and vimentin expression levels were increased based on the magnitude of strain (43). These smooth muscle markers ( $\alpha$-SMA, desmin and vimentin) may be involved in the regulation of smooth muscle movement, and SMCs in vitro may have lost motility, such that the conversion from contractile to synthetic phenotypes could be triggered in vitro. The mechanisms underlying these differences in expression have not been studied in the present study. The expression and regulation of the corresponding biomarkers in smooth muscles or SMCs cultured in vitro, and their relationships with cell phenotypic transformation require further study. To further identify SMCs, PCNA (20-22) was used to detect the proliferation potential. PCNA is mainly synthesized and stored in the nucleus, and participates in the synthesis of DNA (20-22). When comparing the PCNA mRNA, not all SMCs cultured in vitro demonstrated greater expression than that of corresponding tissues; moreover, mRNA and protein expression trends differed in cultured cells. According to the results of the CCK-8 assay, SMCs cultured in 10\%-F12 exhibited poor proliferation; thus, the inconsistency of PCNA might be attributed to modified protein synthesis in the ED (10\%-F12) condition.

The cell types in smooth muscles include SMCs (4), myofibroblasts $(7,12,44)$, fibroblasts $(45)$, telocytes $(32)$ and gastrointestinal Cajal interstitial cells $(4,46)$. A limitation of the present study was the purification and differentiation of 
SMCs in vitro. The problems involved in primary isolation and culture of SMCs with respect to the purity of cells, which are often discussed by researchers, were assessed. Furthermore, the main cells involved in the present study were SMCs. The primary cell specimens must be smooth muscle tissue, and it was ensured that there were no cells from other tissue sources present. Patented SMCM was selected to ensure that the in vitro culture process was more conducive to the growth and proliferation of SMCs. Smooth muscle specimens and cells should be identified by several smooth muscle markers in order to clarify the expression level and characteristics of cell markers in vitro. Also, the present study could not guarantee that all the obtained cells were SMCs; to the best of the authors' knowledge, there is no precise method of identification and purification of SMCs. Previous studies summarize various methods for primary cell culture $(1-3,15)$. Other studies have used these methods for isolation and culture of primary cells $(4,5,7-9,33)$; however, the mechanisms of primary cell differentiation remain unclear. To the best of the authors' knowledge, the only effective approach for cell differentiation is to use primary cells as soon as possible. Previous studies have focused on the mechanisms by which SMCs differentiate in conditions of vascular pathophysiology $(47,48)$. At present, to the best of the authors' knowledge, there is not a detailed investigation of the mechanisms by which esophageal SMCs differentiate into fibroblasts in vitro; therefore, these complex mechanisms require further investigation.

In conclusion, SMCs of EGJ could be cultured in vitro. In the present study, the most effective isolation method of primary cells was EI with low collagenase II concentration $(0.5 \mathrm{mg} / \mathrm{ml})$ combined with low temperature $\left(4^{\circ} \mathrm{C}\right)$ for $14-24 \mathrm{~h}$; SMCs of EC, EL, GC-S and GC-C cultured in 10\%-F12 exhibited superior smooth muscle phenotypes compared with SMCs cultured in SMCM in terms of smooth muscle marker expression. Further studies should be performed regarding SMC phenotype transformation in vivo and in vitro, in addition to studies regarding motor function of smooth muscles in EGJ.

\section{Acknowledgements}

The authors would like to thank Dr Ryan Chastain-Gross, (a postdoctoral researcher in Urology at the University of Florida), for editing the English text of a draft of this manuscript.

\section{Funding}

No funding was received.

\section{Availability of data and materials}

All data generated or analyzed during this study are included in this published article.

\section{Authors' contributions}

JFL designed the study. YG performed experiments, collated data and drafted manuscript. CZ, LL and SLZ proposed improvements of the experiments, performed primary cell culture and revised the manuscript. YPL and LMZ interpreted the results of hematoxylin-eosin staining and immunohistochemistry experiments. All authors read and approved the final manuscript.

\section{Ethics approval and consent to participate}

The present study was approved by The Medical Ethics Committee of The Fourth Hospital of Hebei Medical University. Informed consent was obtained from all patients or their authorized relatives.

\section{Patient consent for publication}

Not applicable.

\section{Competing interests}

The authors declare that they have no competing interests.

\section{References}

1. Proudfoot D and Shanahan C: Human vascular smooth muscle cell culture. Methods Mol Biol 806: 251-264, 2012.

2. Metz RP, Patterson JL and Wilson E: Vascular smooth muscle cells: Isolation, culture, and characterization. Methods Mol Biol 843: 169-176, 2012.

3. Villa-Bellosta R and Hamczyk MR: Isolation and culture of aortic smooth muscle cells and in vitro calcification assay. Methods Mol Biol 1339: 119-130, 2015.

4. Wallace AS and Burns AJ: Development of the enteric nervous system, smooth muscle and interstitial cells of Cajal in the human gastrointestinal tract. Cell Tissue Res 319: 367-382, 2005.

5. Wang J, Laurier LG, Sims SM and Preiksaitis HG: Enhanced capacitative calcium entry and TRPC channel gene expression in human LES smooth muscle. Am J Physiol Gastrointest Liver Physiol 284: G1074-G1083, 2003.

6. Deshpande MA, Wang J, Preiksaitis HG, Laurier LG and Sims SM: Characterization of a voltage-dependent $\mathrm{Na}(+)$ current in human esophageal smooth muscle. Am J Physiol Cell Physiol 283: C1045-C1055, 2002.

7. Gargus $\mathrm{M}, \mathrm{Niu} \mathrm{C}$ and Shaker A: Isolation of myofibroblasts from mouse and human esophagus. J Vis Exp 52215, 2015.

8. Chen X, Zheng Y, Manole CG, Wang X and Wang Q: Telocytes in human oesophagus. J Cell Mol Med 17: 1506-1512, 2013

9. Zhu Y and Chan-Park MB: Density quantification of collagen grafted on biodegradable polyester: Its application to esophageal smooth muscle cell. Anal Biochem 363: 119-127, 2007.

10. Bautista-Cruz F, Nair DG, Lourenssen S, Miller DV, Blennerhassett MG and Paterson WG: Impaired platelet-derived growth factor receptor expression and function in cultured lower esophageal sphincter circular smooth muscle cells from W/W(v) mutant mice. Can J Physiol Pharmacol 92: 34-41, 2014.

11. Rieder F, Cheng L, Harnett KM, Chak A, Cooper GS, Isenberg G, Ray M, Katz JA, Catanzaro A, O'Shea R, et al: Gastroesophageal reflux disease-associated esophagitis induces endogenous cytokine production leading tomotor abnormalities. Gastroenterology 132: 154-165, 2007.

12. Niu C, Chauhan U, Gargus M and Shaker A: Generation and characterization of an immortalized human esophageal myofibroblast line. PLoS One 11: e0153185, 2016.

13. Huber A and Badylak SF: Phenotypic changes in cultured smooth muscle cells: Limitation or opportunity for tissue engineering of hollow organs? J Tissue Eng Regen Med 6: 505-511, 2012.

14. Franck D, Chung YG, Coburn J, Kaplan DL, Estrada CR Jr and Mauney JR: In vitro evaluation of bi-layer silk fibroin scaffolds for gastrointestinal tissue engineering. J Tissue Eng 5: 2041731414556849, 2014.

15. Aji K, Maimaijiang M, Aimaiti A, Rexiati M, Azhati B, Tusong H and Cui L: Differentiation of human adipose derived stem cells into smooth muscle cells is modulated by CaMKII $\gamma$. Stem Cells Int 2016: 1267480, 2016. 
16. Yamamura H, Masuda H, Ikeda W, Tokuyama T, Takagi M, Shibata N, Tatsuta M and Takahashi K: Structure and expression of the human SM22alpha gene, assignment of the gene to chromosome11, and repression of the promoter activity by cytosine DNA methylation. J Biochem 122: 157-167, 1997.

17. Patel JJ, Srivastava S and Siow RC: Isolation, culture, and characterization of vascular smooth muscle cells. Methods Mol Biol 1430: 91-105, 2016.

18. Peng G, Xu J, Liu R, Fu Z, Li S, Hong W, Chen J, Li B and Ran P: Isolation, culture and identification of pulmonary arterial smooth muscle cells from rat distal pulmonary arteries. Cytotechnology 69: 831-840, 2017.

19. Liu JF, Sun J and Drew PA: Characterization of excitatory and inhibitory motor neurons to the human gastric clasp and sling fibers. Can J Physiol Pharmacol 89: 617-622, 2011.

20. Juríková M, Danihel L, Polák Š and Varga I: Ki67, PCNA, and MCM proteins: Markers of proliferation in the diagnosis of breast cancer. Acta Histochem 118: 544-552, 2016.

21. Anggorowati N, Ratna Kurniasari Ch, Damayanti K, Cahyanti T, Widodo I, Ghozali A, Romi MM, Sari DC and Arfian N: Histochemical and immunohistochemical study of $\alpha$-SMA, collagen, and PCNA in epithelial ovarian neoplasm. Asian Pac J Cancer Prev 18: 667-671, 2017.

22. Goodlad RA: Quantification of epithelial cell proliferation, cell dynamics, and cell kinetics in vivo. Wiley Interdiscip Rev Dev Biol 6: e274, 2017.

23. Soslow RA, Dannenberg AJ, Rush D, Woerner BM, Khan KN, Masferrer J and Koki AT: Cox-2 is expressed in human pulmonary, colonic, and mammary tumors. Cancer 89: 2637-2645, 2000.

24. Schmittgen TD and Livak KJ: Analyzing real-time PCR data by the comparative C(T) method. Nat Protoc 3: 1101-1108, 2008.

25. Czarny P, Wigner P, Strycharz J, Swiderska E, Synowiec E, Szatkowska M, Sliwinska A, Talarowska M, Szemraj J, Su KP, et al: Mitochondrial DNA copy number, damage, repair and degradation in depressive disorder. World J Biol Psychiatry 13: 1-11, 2019.

26. Jia QW, Chen ZH, Ding XQ, Liu JY, Ge PC, An FH, Li LH, Wang LS, Ma WZ, Yang ZJ and Jia EZ: Predictive effects of circulating miR-221, miR-130a and miR-155 for coronary heart disease: A multi-ethnic study in China. Cell Physiol Biochem 42: 808-823, 2017.

27. Henrich CJ: Microplate-based nonradioactive protein synthesis assay: Application to TRAIL sensitization by protein synthesis inhibitors. PLoS One 11: e0165192, 2016.

28. Williamson DF, Parker RA and Kendrick JS: The box plot: A simple visual method to interpret data. Ann Intern Med 110: 916-921, 1989

29. Bulluck H, Fröhlich GM, Nicholas JM, Mohdnazri S, Gamma R, Davies J, Sirker A, Mathur A, Blackman D, Garg P, et al: Mineralocorticoid receptor antagonist pre-treatment and early post-treatment to minimize reperfusion injury after ST-elevation myocardial infarction: The MINIMIZE STEMI trial. Am Heart J 211: 60-67, 2019.

30. Xue Y, Qian H, Hu J, Zhou B, Zhou Y, Hu X, Karakhanyan A, Pang Z and Fu XD: Sequential regulatory loops as key gatekeepers for neuronal reprogramming in human cells. Nat Neurosci 19: 807-815, 2016.

31. Liu W and Lin HS: Application of SPSS in multiple comparison Nemenyi rank sum test for multiple samples with completely randomized designs. Chin J Health Statistics 26: 214, 216, 2009 (In Chinese)

32. Xie C, Ritchie RP, Huang H, Zhang J and Chen YE: Smooth muscle cell differentiation in vitro: Models and underlying molecular mechanisms. Arterioscler Thromb Vasc Biol 31: 1485-1494, 2011.

33. Hayashi K, Ando N, Ozawa S, Kitagawa Y, Miki H, Sato M and Kitajima M: A neo-esophagus reconstructed by cultured human esophageal epithelial cells, smooth musclecells, fibroblasts, and collagen. ASAIO J 50: 261-266, 2004.
34. Gao Y, Liu JF, He X, Liu XB, Zhang LL, Zhao LM and Zhang C: Calcium receptor and nitric oxide synthase expression in circular muscle of lower esophagus from patients with achalasia. Chin Med J (Engl) 131: 2882-2885, 2018.

35. Beppu LY, Anilkumar AA, Newbury RO, Dohil R, Broide DH and Aceves SS: TGF- $\beta 1$-induced phospholamban expression alters esophageal smooth muscle cell contraction in patients with eosinophilic esophagitis. J Allergy Clin Immunol 134: $1100-1107,2014$

36. Muir AB, Dods K, Henry SJ, Benitez AJ, Lee D, Whelan KA, De Marshall M, Hammer DA, Falk G, Wells RG, et al: Eosinophilic esophagitis-associated chemical and mechanical microenvironment shapes esophageal fibroblast behavior. J Pediatr Gastroenterol Nutr 63: 200-209, 2016.

37. Ryan US: Isolation and culture of pulmonary endothelial cells. Environ Health Perspect 56: 103-114, 1984

38. Lou JN, Mili N, Decrind C, Donati Y, Kossodo S, Spiliopoulos A, Ricou B, Suter PM, Morel DR, Morel P and Grau GE: An improved method for isolation of microvascular endothelial cells from normal and inflamed human lung. In Vitro Cell Dev Biol Anim 34: 529-536, 1998.

39. Woo JG, Park SY, Lim JC, Joo MJ, Kim HR and Sohn UD: Acid-induced COX-2 expression and prostaglandin E2 production via activation of ERK1/2 and p38 MAPK in cultured feline esophageal smooth muscle cells. Arch Pharm Res 34: 2131-2140, 2011.

40. Jensen T, Blanchette A, Vadasz S, Dave A, Canfarotta M, Sayej WN and Finck C: Biomimetic and synthetic esophageal tissue engineering. Biomaterials 57: 133-141, 2015.

41. Grünwald J, Mey J, Schönleben W, Hauss J and Hauss WH: Cultivated human arterial smooth muscle cells. The effect of donor age, blood pressure, diabetes and smoking on in vitro cell growth. Pathol Biol (Paris) 31: 819-823, 1983.

42. Zhang H, Fazel S, Tian H, Mickle DA, Weisel RD, Fujii T and Li RK: Increasing donor age adversely impacts beneficial effects of bone marrow but not smooth muscle myocardial cell therapy. Am J Physiol Heart Circ Physiol 289: H2089-H2096, 2005.

43. Ritchie AC, Wijaya S, Ong WF, Zhong SP and Chian KS: Dependence of alignment direction on magnitude of strain in esophageal smooth muscle cells. Biotechnol Bioeng 102: 1703-1711, 2009.

44. El Mourabit H, Loeuillard E, Lemoinne S, Cadoret A and Housset C: Culture model of rat portal myofibroblasts. Front Physiol 7: 120, 2016

45. Sinzger C, Grefte A, Plachter B, Gouw AS, The TH and Jahn G: Fibroblasts, epithelial cells, endothelial cells and smooth muscle cells are major targets of human cytomegalovirus infection in lung and gastrointestinal tissues. J Gen Virol 76: 741-750, 1995.

46. Faussone-Pellegrini MS, Cortesini C and Romagnoli P: The ultrastructure of the muscle coat of human gastro-oesophageal junction, with special reference to 'interstitial cells of Cajal'. Front Neurosci 7: 49, 2013.

47. Kumar A, D'Souza SS, Moskvin OV, Toh H, Wang B, Zhang J, Swanson S, Guo LW, Thomson JA and Slukvin II: Specification and diversification of pericytes and smooth muscle cells from mesenchymoangioblasts. Cell Rep 19: 1902-1916, 2017.

48. Lao KH, Zeng L and Xu Q: Endothelial and smooth muscle cell transformation in atherosclerosis. Curr Opin Lipidol 26: 449-456, 2015.

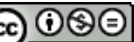

This work is licensed under a Creative Commons Attribution-NonCommercial-NoDerivatives 4.0 International (CC BY-NC-ND 4.0) License. 